\title{
The effects of recent control policies on trends in emissions of anthropogenic atmospheric pollutants and $\mathrm{CO}_{2}$ in China
}

\author{
Y. Zhao ${ }^{1}$, J. Zhang ${ }^{2}$, and C. P. Nielsen ${ }^{3}$ \\ ${ }^{1}$ State Key Laboratory of Pollution Control \& Resource Reuse and School of the Environment, Nanjing University, 163 \\ Xianlin Ave., Nanjing, Jiangsu 210023, China \\ ${ }^{2}$ Jiangsu Provincial Academy of Environmental Science, 241 West Fenghuang St., Nanjing, Jiangsu 210036, China \\ ${ }^{3}$ Harvard China Project, School of Engineering and Applied Sciences, Harvard University, 29 Oxford St, Cambridge, MA \\ 02138, USA
}

Correspondence to: Y. Zhao (yuzhao@nju.edu.cn)

Received: 27 July 2012 - Published in Atmos. Chem. Phys. Discuss.: 21 September 2012

Revised: 25 December 2012 - Accepted: 4 January 2013 - Published: 16 January 2013

\begin{abstract}
To examine the effects of China's national policies of energy conservation and emission control during 20052010, inter-annual emission trends of gaseous pollutants, primary aerosols, and $\mathrm{CO}_{2}$ are estimated with a bottom-up framework. The control measures led to improved energy efficiency and/or increased penetration of emission control devices at power plants and other important industrial sources, yielding reduced emission factors for all evaluated species except $\mathrm{NO}_{\mathrm{x}}$. The national emissions of anthropogenic $\mathrm{SO}_{2}$, $\mathrm{CO}$, and total primary PM (particulate matter) in 2010 are estimated to have been $89 \%, 108 \%$, and $87 \%$ of those in 2005 , respectively, suggesting successful emission control of those species despite fast growth of the economy and energy consumption during the period. The emissions of $\mathrm{NO}_{\mathrm{x}}$ and $\mathrm{CO}_{2}$, however, are estimated to have increased by $47 \%$ and $43 \%$, respectively, indicating that they remain largely determined by the growth of energy use, industrial production, and vehicle populations. Based on application of a Monte-Carlo framework, estimated uncertainties of $\mathrm{SO}_{2}$ and $\mathrm{PM}$ emissions increased from 2005 to 2010 , resulting mainly from poorly understood average $\mathrm{SO}_{2}$ removal efficiency in flue gas desulfurization (FGD) systems in the power sector, and unclear changes in the penetration levels of dust collectors at industrial sources, respectively. While emission trends determined by bottom-up methods can be generally verified by observations from both ground stations and satellites, clear discrepancies exist for given regions and seasons, indicating a need for more accurate spatial and time distributions of emissions. Limitations of current emission control polices
\end{abstract}

are analyzed based on the estimated emission trends. Compared with control of total PM, there are fewer gains in control of fine particles and carbonaceous aerosols, the PM components most responsible for damages to public health and effects on radiative forcing. A much faster decrease of alkaline base cations in primary $\mathrm{PM}$ than that of $\mathrm{SO}_{2}$ may have raised the acidification risks to ecosystems, indicating further control of acid precursors is required. Moreover, with relatively strict controls in developed urban areas, air pollution challenges have been expanding to less-developed neighboring regions. There is a great need in the future for multipollutant control strategies that combine recognition of diverse environmental impacts both in urban and rural areas with emission abatement of multiple species in concert.

\section{Introduction}

China suffers highly degraded air quality and related environmental impacts, mainly due to intensive fossil fuel consumption and rapid growth of the vehicle population. Based on satellite observations and chemical transport models, eastern China has been found to have the highest concentrations of airborne fine particulate matter $\left(\mathrm{PM}_{2.5}\right)$ (van Donkelaar et al., 2010) and vertical column densities (VCD) of tropospheric $\mathrm{NO}_{2}$ (Richter et al., 2005) in the world. Serious air pollution has caused huge public health damages particularly in mega cities (Parrish and Zhu, 2009) and has also threatened ecosystems. The highest acidity of precipitation 
in the world has been observed in south and southwest China (Larssen et al., 2006). A number of analysts have estimated swift increases in anthropogenic emissions, the main cause of China's severe air pollution, during the early-2000s (Ohara et al, 2007; Zhang et al., 2007; Lu et al., 2010; Lei et al., 2011a). According to the GAINS model developed by the International Institute for Applied Systems Analysis (IIASA), China accounted for $24 \%, 14 \%, 25 \%$, and $27 \%$ of global emissions of $\mathrm{SO}_{2}, \mathrm{NO}_{\mathrm{x}}$, black carbon (BC), and organic carbon (OC) in 2000, respectively (Cofala et al., 2007; Klimont et al., 2009). Although considerable uncertainties exist (Zhao et al., 2011a), estimates of China's total $\mathrm{SO}_{2}$ and PM emissions are much more than those of the US or Europe (Zhao et al., 2009; 2011b).

Under heavy pressure to improve urban air quality, reduce regional air pollution, and limit carbon emissions, China's government has implemented a comprehensive national policy strategy of energy conservation and emission reduction since 2005. Its goal is to shift the country's development mode from one dependent on intense fossil energy inputs with consequent high emissions to a more resource-efficient and environment-friendly alternative. Stringent, compulsory measures to improve energy efficiency and control emissions have been required at many major source types, targeting a range of atmospheric pollutants. These measures include: replacement of small and inefficient plants or boilers with larger, energy-efficient ones in the power sector and certain heavy industrial sectors including cement production; installation of flue gas desulfurization (FGD) systems at all newly built thermal power units; application of more stringent emission standards in cement production; and staged implementation of tighter emission standards on vehicles. Evidence of success of these measures since 2005 has been confirmed in different ways. For example, improved combustion efficiency (and thus energy efficiency) is indicated in an increasing inter-annual trend in the ratio of $\mathrm{CO}_{2}$ to $\mathrm{CO}$, because $\mathrm{CO}_{2}$ results from complete combustion and $\mathrm{CO}$ from incomplete combustion of carbon fuels. The trend has been observed instrumentally in air masses representative of north China emissions at a rural site north of Beijing (Wang et al., 2010a) and also indicated in bottom-up emission inventory studies (Zhao et al., 2012a, b). Reductions in regional and national $\mathrm{SO}_{2}$ are similarly indicated both by observations, from satellites (Li et al., 2010), and by bottom-up emission trends based on fast-track energy statistics for recent years (Lu et al., 2010; 2011). Some studies also assess the effects of policies on other species including $\mathrm{NO}_{\mathrm{x}}$ (Lin et al., 2011; Wang et al., 2012) and primary and secondary aerosols (Lu et al., 2011; Lin et al., 2010a).

While studies that focus on individual species and/or source types are essential to building fundamental knowledge of atmospheric processes in China, they contribute piecemeal to understanding of China's atmospheric environment as an integrated system of sources and sinks of diverse reactive species. Interaction of emission trends, however, is often as significant to environmental outcomes of interest as the trend in any one species or source category taken alone. This is critical not only to understanding physical, chemical, and biological cycles but also to evaluating and informing the development of broadly effective air quality and climate protection policy strategies. The current study meets a need for comprehensive consideration of emission trends of different atmospheric pollutants and analyses of the main drivers of these trends. It focuses on 2005 through the end of China's $11^{\text {th }}$ Five Year Plan in 2010, a discrete period of sharply heightened regulatory action in emission control.

The study analyzes the effects of recently implemented control measures on the inter-annual trends, sector and spatial distributions, and uncertainties of China's anthropogenic emissions. Incorporating the latest information from domestic field measurements and investigations, the trends of emission factors (i.e., the emission levels per unit consumption of energy or industrial production) for different kinds of pollutants from 2005 to 2010 are developed by sector and technology. Based on a bottom-up framework, provincial and national emissions are estimated for 2005-2010, indicating the effectiveness of improved energy efficiency and emission control efforts during those years. The uncertainties of emissions in 2010 are quantified statistically using Monte-Carlo simulation, which was developed and applied previously to emissions for 2005 (Zhao et al., 2011a). The causes of discrepancies between the uncertainty results for the two years are evaluated. To understand the effects of varied emissions on urban and regional air quality, available observations from ground measurements and satellites are reviewed and compared with the bottom-up emissions for corresponding time periods and locations in China. Limitations of current controls on diverse environmental impacts are analyzed based on the estimated emission trends for different species and regions, recommending a more comprehensive, multi-pollutant scope as China develops its future strategies in control of atmospheric pollutants.

\section{Methods}

\subsection{The framework of the emission inventory}

The methods of developing a bottom-up emission inventory are detailed in previous studies (Zhao et al., 2011a, 2012a). Figure S1 in the Supplement shows the source structure used to estimate China's anthropogenic atmospheric emissions. At the largest scale, sources fall into four main sector categories: coal-fired power plants (CPP), all other industry (IND), transportation (TRA, including on-road and non-road subcategories), and the residential \& commercial sector (RES, including fossil fuel and biomass combustion subcategories). IND is further divided into cement production (CEM), iron \& steel plants (ISP), other industrial boilers (OIB), and other non-combustion processes (PRO), 


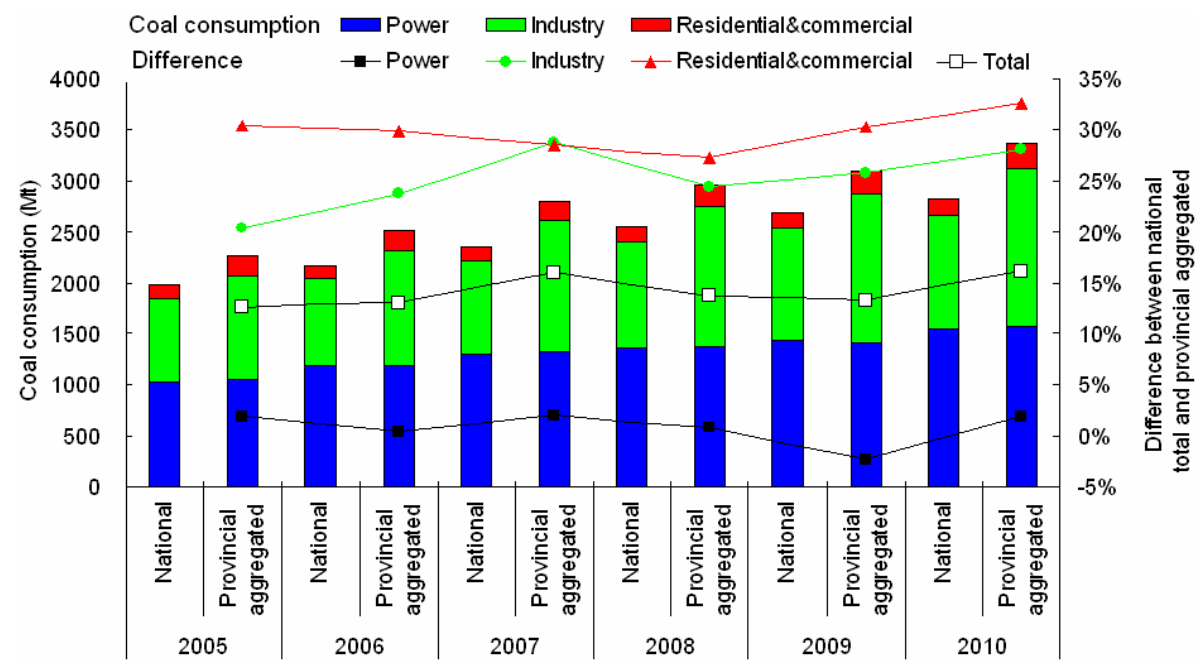

Fig. 1. China's coal consumption by sector and the relative difference between the national total statistics and aggregation of provincial statistics from 2005 to 2010 .

reflecting the structure of available data. Species considered in this work include gaseous pollutants $\left(\mathrm{SO}_{2}, \mathrm{NO}_{\mathrm{x}}\right.$, and $\left.\mathrm{CO}\right)$, $\mathrm{PM}$ according to different size classes and chemical species (Total Suspended Particles (TSP), $\mathrm{PM}_{10}, \mathrm{PM}_{2.5}, \mathrm{BC}$, OC, $\mathrm{Ca}$, and $\mathrm{Mg}$ ), and the greenhouse gas $\mathrm{CO}_{2}$. Annual anthropogenic emissions of these pollutants for 2005-2010 are estimated both by province and sector and then aggregated to the national level, using Eq. (1):

$E_{i, j, t}=$

$\sum_{k} \sum_{m} \sum_{n} \mathrm{AL}_{j, k, m, n, t} \times \mathrm{EF}_{i, j, k, m, t} \times R_{j, k, m, n, t} \times\left(1-\eta_{i, n, t}\right)$

where $i, j, k, m, n$ and $t$ stand for species, province, sector, fuel type, emission control technology and year, respectively; $\mathrm{AL}$ is the activity level, either energy consumption or industrial production; $\mathrm{EF}$ is the unabated emission factor; $R$ is the penetration rate of emission control technology; and $\eta$ is the removal efficiency.

\subsection{Activity levels}

Activity levels for 2005-2010 are compiled annually by sector from various data sources. The fossil fuel consumption and industrial production at provincial level are obtained from Chinese official energy (NBS, 2011a) and industrial economy statistics (NBS, 2011b). For some industrial sources without official statistics, such as brick making, internal production data from relevant associations have to be relied on. To avoid double counting, the fuel consumption by OIB is estimated by subtracting the fuel consumed by CEM, ISP and PRO from fuel consumed by total industry (Zhao et al., 2012a). The amount of biofuel use is taken from official statistics (NBS, 2011a). The biomass combusted in open fields is calculated as a product of grain production, waste-tograin ratio, and the percentage of residual material burned in the field. Details are described in Zhao et al. (2011a; 2012a). From 2006 to 2010, the share of primary energy consumption by coal decreased from $74 \%$ to $70 \%$, indicating a shift towards cleaner energy sources.

It should be noted that China's provincial and national energy statistics are often inconsistent, and such inconsistence can lead to considerable deviations in emission estimate (Guan et al., 2012). As shown in Fig. 1, the annual coal consumption levels reported officially for the entire country range $13-16 \%$ lower than the sum of provincial consumption in each year from 2005 to 2010 . On a sector basis, the differences reach $20-30 \%$ for industry and exceed $30 \%$ for the residential and commercial sector, while the difference for the power sector is relatively small $(\sim 2 \%)$. Akimoto et al. (2006) found China's provincial-level statistics to be within the uncertainty bounds of the satellite record of $\mathrm{NO}_{2}$ over the country while the national-level statistics were not, and advised against use of the latter for emission inventories in China. Although this conclusion was drawn for 1996-2002, the differences between the national and aggregated provincial statistics have not diminished in following years. Subsequent studies of China's emissions, many including comparisons to observations by ground stations, aircraft, or satellites, have held to the same conclusion (Streets et al. 2006; Zhang et al., 2007; Zhao et al., 2012b). We likewise believe that the provincial statistics are more accurate than the national ones.

For transportation, Chinese official statistics reflect only fuel used in commercial activities, and thus cannot be applied directly. In this work, on-road vehicles are classified into light-duty gasoline vehicles (LDGV), light-duty gasoline trucks (LDGT), light-duty diesel trucks (LDDT), heavyduty gasoline vehicles (HDGV), heavy-duty diesel vehicles (HDDV), and motorcycles (MC). The oil consumption by 


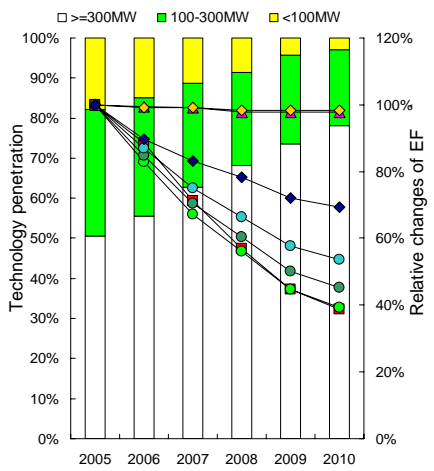

(a) Coal-fired power plants

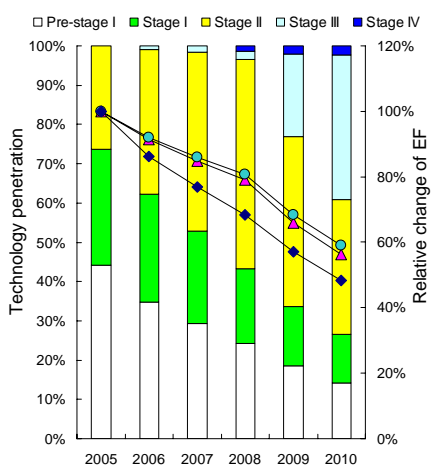

(d) Light-duty gasoline vehicles

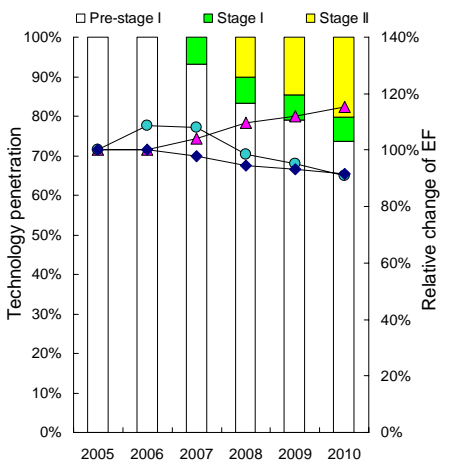

(g) Rural vehicles

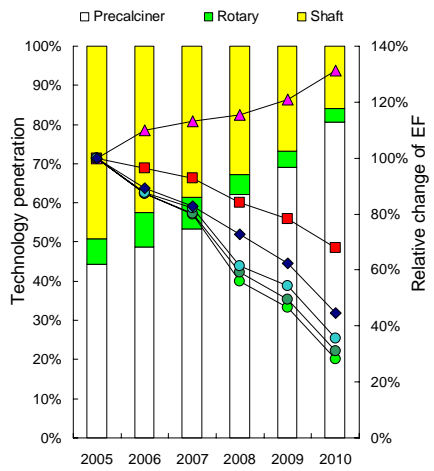

(b) Cement production

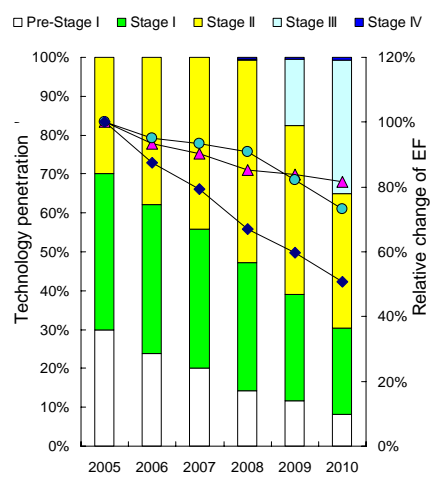

(e) Heavy-duty diesel vehicles

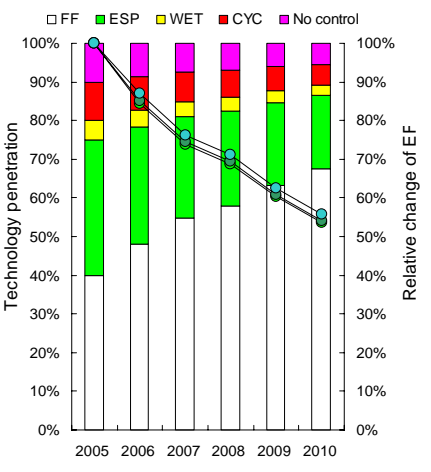

(h) Nonferrous metallurgy

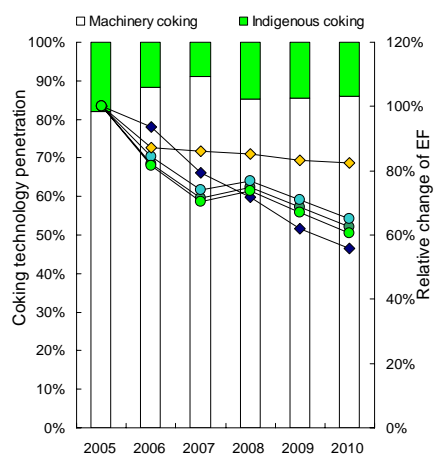

(c) Iron \& steel production

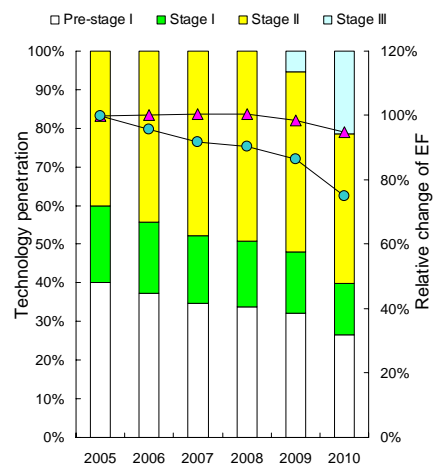

(f) Motorcycles

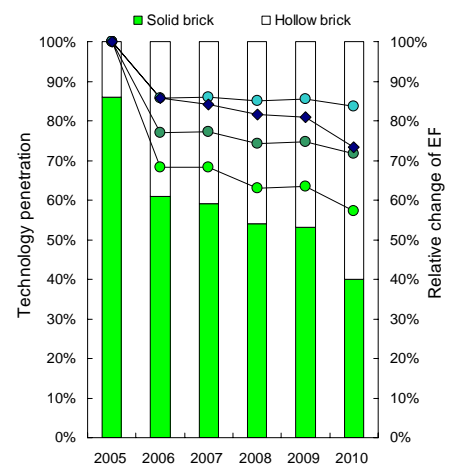

(i) Brick production

$\neg$ SO2 $\triangle$ NOx $\rightarrow$ TSP $\rightarrow$ PM10 $\rightarrow$ PM2.5 $\neg \mathrm{CO} \leadsto-\mathrm{CO} 2$

Fig. 2. The penetrations of technologies and inter-annual trends of emission factors for typical sources in China from 2005 to 2010 . In each panel, left-hand vertical axis indicates the percentages of various technologies and right-hand vertical axis indicates the relative changes of emission factors for various species.

each vehicle type is calculated as the product of the vehicle population, annual average mileage traveled per vehicle, and average fuel economy of the corresponding type (He et al., 2005). The updated data are provided in Huo et al. (2011, 2012a, b) and Zhao et al. (2012a). For non-road sources including railway, waterway, rural vehicles, and construction equipment, the fuel consumption in 2005 is taken from Zhang et al. (2008), while those for 2006-2010 are scaled by province according to the growth of passenger and freight traffic by rail and shipping, and the total growth of agricul- tural and construction equipment. All those data are obtained from official statistics (NBS, 2011c).

\section{Evolution of emission factors}

Driven mainly by official Chinese policies, the penetration levels of different energy efficiency technologies and emission control devices shifted considerably at the national level from 2005 to 2010, leading to strong changes in emission factors as clearly illustrated in Fig. 2. Details by source are 
discussed as follows. During the period of interest, the mass fractions of $\mathrm{BC}$ and $\mathrm{OC}$ in PM for industrial and transportation sectors, and those of $\mathrm{Ca}$ and $\mathrm{Mg}$ for all the related sectors are assumed unchanged, taken from Zhao et al. (2011a) and Zhu et al. (2004). It should be noted that such assumption will elevate uncertainty since the fractions of chemical compositions in PM are not always constant along with technology change for given sources. For example, increased share of $\mathrm{BC}$ in $\mathrm{PM}$ emissions has been reported for newer vehicles with improved technology (Zielinska et al., 2004). In China, however, domestic measurements are still insufficient for evaluating the clear tends of chemical fractions in PM, particularly for a relatively short period. Long-term analysis of PM emission factors with chemical species profiles are thus recommended for future.

\subsection{Coal-fired power plants}

Coal-fired power plants were targeted for the most stringent emission controls during 2005-2010, particularly for $\mathrm{SO}_{2}$. According to a unit-based dataset of coal-fired power plants over the country (Zhao et al., 2008), the FGD penetration rate increased from $13 \%$ of total capacity in 2005 to $86 \%$ in 2010 , and the capacity share of the units equal to or larger than $300 \mathrm{MW}$ rose from $51 \%$ in 2005 to $78 \%$ in 2010 , as shown in Fig. 2a. Based on an unpublished official survey, the national average removal efficiency of FGD is set at $75 \%$ in this study, resulting in a $61 \%$ reduction in the $\mathrm{SO}_{2}$ emission factor for the entire coal-fired power sector over 20052010. Fast growth of large power units with higher energy efficiency and advanced PM control devices like electrostatic precipitators (ESP) or fabric filters $(\mathrm{FF})$ reduced the emission factors of $\mathrm{CO}$ and $\mathrm{PM}$ as well. Based on an emission factor database reported by Zhao et al. (2010, 2012a), the emission factors of TSP, $\mathrm{PM}_{10}, \mathrm{PM}_{2.5}$, and $\mathrm{CO}$ are respectively estimated to have decreased $60 \%, 55 \%, 46 \%$, and $31 \%$ from 2005 to 2010. (Note that increased wet-FGD also helped to reduce PM emissions due to its ancillary benefit on PM removal (Zhao et al., 2010)).

On the other hand, however, the emission factors of $\mathrm{NO}_{\mathrm{x}}$ and $\mathrm{CO}_{2}$ for coal-fired power plants varied little from 2005 to 2010 , due to the limited addition of selective catalytic/noncatalytic reduction (SCR/SNCR) and the experimental state of carbon capture and storage technologies. It should be noted that the emission factors here are expressed as the mass of emitted pollutants per unit consumption of coal. If evaluated as pollutants per unit of generated electricity, the emission factors of $\mathrm{NO}_{\mathrm{x}}$ and $\mathrm{CO}_{2}$ declined by $12 \%$ and $19 \%$, respectively, resulting mainly from the improved energy efficiency of coal-fired power generation during the years of analysis.

\subsection{Cement production}

Cement kiln technologies in China include shaft, precalciner, and other rotary kilns. As shown in Fig. 2b, the penetration of precalciner kilns, the most energy-efficient technology, increased from $44 \%$ to $81 \%$ from 2005 to 2010 , while that of shaft kilns declined from $49 \%$ to $16 \%$, according to official statistics. Emission factors of cement production by technology have been compiled by Lei et al. (2011b). Newly built precalciner kilns with ESP or FF lead to reduced emission factors for PM and CO. However, such benefits are accompanied by an increased $\mathrm{NO}_{\mathrm{x}}$ emission factor, because the higher operational temperatures and more automated air-flow systems of precalciner kilns increase emissions of $\mathrm{NO}_{\mathrm{x}}$ compared to shaft kilns. Combining the emission factors by Lei et al. (2011b) and changes in penetration of different kiln types, the emission factors (expressed as pollutants per unit of cement production) for $\mathrm{SO}_{2}, \mathrm{TSP}, \mathrm{PM}_{10}, \mathrm{PM}_{2.5}$, and $\mathrm{CO}$ are estimated to have declined by $32 \%, 72 \%, 69 \%, 64 \%$, and $55 \%$, respectively, during 2005-2010, while that for $\mathrm{NO}_{\mathrm{x}}$ increased by $31 \%$. Since $\mathrm{CO}_{2}$ is generated mainly from the non-combustion process of carbonate calcination (Zhao et al., 2012b), the technology changes in cement production yielded little mitigation of $\mathrm{CO}_{2}$ emissions.

\subsection{Iron and steel production}

The iron and steel industry employs the following processes: coking, sintering, pig iron making (in blast furnaces), steel making (nearly $90 \%$ of which is in basic oxygen furnaces), and casting. $\mathrm{SO}_{2}$ and $\mathrm{NO}_{\mathrm{x}}$ come mainly from the sintering process, and those emission factors are assumed unchanged during 2005-2010 given no new control requirements.

Based on national statistics (CISA, 2011), the share of coke produced in machinery coking ovens (versus modified indigenous ovens with poor technology and manual operation) increased from $82 \%$ in 2005 to $86 \%$ in 2010, reaching a peak of $91 \%$ in 2007 . Due to improved use of waste heat, the release ratios of machinery coke oven gas declined from $5.7 \%$ to $1.4 \%$ between 2005 and 2010 . The release ratio of blast furnace flue gas in the making of pig iron dropped from $8.4 \%$ to $5.0 \%$ in the same period, and the recycled flue gas in basic oxygen furnaces increased from 60 to $79 \mathrm{Nm}^{3} / \mathrm{t}$-steel (CISA, 2011). Those improvements made the emission factors of PM, CO, and $\mathrm{CO}_{2}$ for the combined processes (expressed as pollutants per unit of steel production) decline by $39 \%, 44 \%$, and $18 \%$, respectively, as shown in Fig. 2c.

\subsection{Transportation}

Since 1999, staged emission standards (Stage I-IV, equivalent to Euro I-IV) for new on-road vehicles have been implemented nationwide, with earlier implementation in Beijing than in other provinces. The fleet compositions by control stages for 2005-2010 are determined based on reported 
annual new-vehicle registrations (NBS, 2011c) and the retirement of old vehicles based on assumed vehicle lifetimes in China by type. The average lifetimes of light-duty vehicles, light-duty trucks, and heavy-duty trucks are assumed to be 15,8 , and $10 \mathrm{yr}$, respectively, based on previous studies (He et al., 2005; Huo et al., 2012b).

As summarized in Tables S1 and S2 in the Supplement, prior measurements of emission factors of $\mathrm{NO}_{\mathrm{x}}$ and $\mathrm{PM}_{2.5}$ for vehicles in China by type and control stage were thoroughly investigated in this work, including on-road tests, engine tests, carbon balance calculations, and remote sensing (see also the database for CO by Zhao et al., 2012a). Results of on-road tests with advanced measurement technologies (e.g., He et al. (2010) and Wu et al. (2012) using SEMTECHD and Oliver (2008) using OBS-2200) are given preference to calculated vehicle emissions. If two or more studies consider the same combination of vehicle type and control stage, the emission factors used here are calculated as the average of the original data weighted by the sampling size. Due to few on-road tests of LDGT, data from roadside remote sensing (Guo et al., 2007) are applied for this vehicle type. With almost no measurements for HDGV or MC by control stage, the standard limits of stage I-II are relied upon, and typical fuel economies $(2.7 \mathrm{~L}-$ fuel $/ 100 \mathrm{~km}$ for $\mathrm{MC}$ (He et al., 2005) and $250 \mathrm{~g}$-fuel $\mathrm{kWh}^{-1}$ for heavy-duty engines (Chen et al., 2008; MIIT, 2010)) are applied to convert the standard limits to fuel-based values. The same assumption is also applied for most non-road sources, except rural vehicles (RV), for which emission factors are taken from on-vehicle tests using SEMTECH-D by Yao et al. (2011). As shown in Fig. 2d, the nationwide emission factor levels of $\mathrm{NO}_{\mathrm{x}}, \mathrm{PM}_{2.5}$, and $\mathrm{CO}$ are estimated to have declined by $44 \%, 41 \%$, and $52 \%$ respectively for LDGV, attributed to implementation of the staged regulations. The control effects for MC, HDDV, and rural vehicles (Fig. 2e-g) are less, particularly for $\mathrm{NO}_{\mathrm{x}}$, and indeed $\mathrm{NO}_{\mathrm{x}}$ emission factors for rural vehicles are estimated to have increased. The reasons include (1) slower penetrations of new MC and rural vehicle technologies than that of LDGV, and (2) higher $\mathrm{NO}_{\mathrm{x}}$ emission rates of diesel engines under recently implemented regulations.

\subsection{Other industrial boilers, processes, and residential and commercial combustion}

For industrial boilers and processes, the primary concern is changes of emission factors for PM, resulting from varied penetration levels of different dust collector technologies. Such information is available for 2005 from investigation by Lei et al. (2011a), but very few data can be found for subsequent years. In this work, we assume that new emission sources (reflected by the annual net growth of energy consumption or industrial production) applied the most advanced dust collectors that have already been deployed in the sector, reflecting the effect of national policies to foster energy conservation and emission reduction during 2006-2010.
For example, the PM emission factors are estimated to have decreased by over $40 \%$ in nonferrous metallurgy, attributed to increased application of FF (Fig. 2h). For brick making, the share of solid clay bricks in China is estimated to have declined from $86 \%$ to $40 \%$ from 2005 to 2010 (Xu and Wang, 2007; Zhou, 2009; Zhao et al., 2012a). Accordingly, the emission factors (expressed as pollutants per unit of brick production) declined by $43 \%, 28 \%, 16 \%$ and $27 \%$ for TSP, $\mathrm{PM}_{10}, \mathrm{PM}_{2.5}$ and $\mathrm{CO}$, respectively (Fig. 2i). Those trends of emission factors, however, should be used with caution, since there are currently very few domestic measurements available for size profiles of PM emissions from brick production, and the results from foreign countries have to be relied on (Klimont et al., 2002).

To examine the sensitivity of PM emissions to the estimated trends of dust collector penetration, we also make an additional case, in which the application rates of dust collectors for industrial boilers and processes are kept unchanged from 2005 to 2010. Comparison of emissions between the two cases is given in Sect. 4.3.

For the residential \& commercial sector, very little progress in emission control is believed to have occurred during 2005-2010 in either fossil fuel consumption or biofuel/biomass burning. Emission factors for different species are mainly from the database compiled by Zhao et al. (2011a; 2012a; b), with most recent results from domestic tests incorporated (Shen et al., 2010, 2012)

\section{Results}

\subsection{Inter-annual emission trends by sector and province}

The national emissions from 2005 to 2010 for different species are illustrated by sector in Fig. 3. The $\mathrm{SO}_{2}$ emissions are estimated to have decreased from 31.1 million metric tons (Mt) in 2005 to $27.7 \mathrm{Mt}$ in 2010 , with a peak value of $32.1 \mathrm{Mt}$ in 2006 (Fig. 3a). It is particularly notable that the emissions from coal-fired power plants declined from 16.3 to $9.2 \mathrm{Mt}$, and the sector share of total emissions from $52 \%$ to $33 \%$, resulting mainly from the swift increase of FGD systems during 2005-2010. The $\mathrm{SO}_{2}$ emissions of other industries, however, are estimated to have increased by $32 \%$, accounting for over half of total national emissions in 2010; this is attributed to the dramatic growth of industrial production and energy consumption. This result confirms previous work on China's $\mathrm{SO}_{2}$ trends (Lu et al., 2011; Zhang et al., 2012a; see also the detailed comparison in Sect. 4.2) and spotlights the industry sector as a key target for future $\mathrm{SO}_{2}$ emission controls, not just power plants. In contrast to $\mathrm{SO}_{2}$, national $\mathrm{NO}_{\mathrm{x}}$ emissions increased dramatically, by $48 \%$ to $29.0 \mathrm{Mt}$ in 2010, attributed to swift growth of energy consumption and limited control measures (Fig. 3b). Specifically, emissions from cement and on-road vehicles are estimated to have increased $131 \%$ and $61 \%$, respectively. Expanded application 
Table 1. Emissions in China 2010 by province (unit: $\mathrm{Mt}$ for $\mathrm{CO}_{2}$ and kilo metric tons (kt) for other species).

\begin{tabular}{|c|c|c|c|c|c|c|c|c|c|c|c|c|}
\hline \multirow{2}{*}{ Province } & \multirow{2}{*}{ Region } & \multicolumn{3}{|c|}{ Gaseous pollutants } & \multicolumn{7}{|c|}{ Primary aerosols } & \multirow{2}{*}{$\begin{array}{c}\mathrm{GHG} \\
\mathrm{CO}_{2}\end{array}$} \\
\hline & & $\mathrm{SO}_{2}$ & $\mathrm{NO}_{\mathrm{x}}$ & $\mathrm{CO}$ & TSP & $\mathrm{PM}_{10}$ & $\mathrm{PM}_{2.5}$ & $\mathrm{BC}$ & $\mathrm{OC}$ & $\mathrm{Ca}$ & $\mathrm{Mg}$ & \\
\hline Beijing & North-central & 187 & 309 & 2267 & 237 & 114 & 78 & 15 & 27 & 36 & 3 & 98 \\
\hline Tianjin & North-central & 351 & 592 & 3003 & 293 & 182 & 137 & 17 & 24 & 24 & 6 & 186 \\
\hline Hebei & North-central & 1942 & 1996 & 16730 & 2351 & 1393 & 1011 & 128 & 197 & 262 & 44 & 782 \\
\hline Shanxi & North-central & 1660 & 1237 & 6639 & 1183 & 653 & 466 & 74 & 127 & 139 & 16 & 443 \\
\hline Inner Mongol & North-central & 1304 & 1244 & 5273 & 950 & 679 & 511 & 90 & 181 & 74 & 14 & 470 \\
\hline Liaoning & Northeast & 1188 & 1334 & 9421 & 1204 & 728 & 524 & 66 & 91 & 136 & 19 & 456 \\
\hline Jilin & Northeast & 356 & 583 & 4168 & 641 & 417 & 301 & 44 & 81 & 52 & 7 & 212 \\
\hline Heilongjiang & Northeast & 309 & 759 & 5258 & 674 & 482 & 371 & 52 & 109 & 41 & 5 & 260 \\
\hline Shanghai & East & 691 & 911 & 4020 & 359 & 211 & 153 & 18 & 15 & 39 & 8 & 194 \\
\hline Jiangsu & East & 1341 & 1877 & 11500 & 1685 & 1041 & 765 & 82 & 157 & 222 & 22 & 710 \\
\hline Zhejiang & East & 909 & 1324 & 5263 & 810 & 447 & 299 & 33 & 45 & 145 & 8 & 413 \\
\hline Anhui & East & 803 & 1177 & 9702 & 1260 & 805 & 630 & 80 & 170 & 116 & 9 & 402 \\
\hline Fujian & East & 486 & 761 & 3414 & 517 & 317 & 213 & 28 & 37 & 76 & 4 & 249 \\
\hline Jiangxi & East & 633 & 574 & 4643 & 1006 & 440 & 284 & 33 & 49 & 262 & 11 & 225 \\
\hline Shandong & East & 3199 & 2589 & 17234 & 2976 & 1718 & 1187 & 160 & 252 & 490 & 44 & 905 \\
\hline Henan & South-central & 1402 & 1866 & 12418 & 2417 & 1247 & 862 & 102 & 175 & 451 & 29 & 683 \\
\hline Hubei & South-central & 1241 & 1102 & 8869 & 1259 & 739 & 530 & 77 & 131 & 161 & 13 & 412 \\
\hline Hunan & South-central & 1036 & 959 & 7423 & 1284 & 758 & 555 & 65 & 138 & 181 & 12 & 336 \\
\hline Guangdong & South-central & 1112 & 1824 & 8834 & 1315 & 733 & 482 & 56 & 81 & 292 & 11 & 607 \\
\hline Guangxi & South-central & 738 & 707 & 7384 & 1029 & 629 & 484 & 58 & 122 & 189 & 8 & 269 \\
\hline Hainan & South-central & 38 & 127 & 674 & 77 & 49 & 37 & 5 & 9 & 17 & 0 & 38 \\
\hline Chongqing & Southwest & 1148 & 485 & 3088 & 508 & 302 & 210 & 31 & 54 & 90 & 3 & 179 \\
\hline Sichuan & Southwest & 1813 & 1074 & 10276 & 1274 & 796 & 587 & 81 & 157 & 211 & 9 & 409 \\
\hline Guizhou & Southwest & 1075 & 751 & 3896 & 691 & 385 & 275 & 57 & 97 & 133 & 6 & 259 \\
\hline Yunnan & Southwest & 616 & 730 & 4440 & 844 & 543 & 392 & 76 & 91 & 108 & 16 & 232 \\
\hline Tibet & Southwest & 1 & 23 & 136 & 9 & 8 & 7 & 1 & 2 & 1 & 0 & 4 \\
\hline Shaanxi & Northwest & 926 & 699 & 4794 & 745 & 400 & 285 & 46 & 81 & 141 & 6 & 276 \\
\hline Gansu & Northwest & 409 & 378 & 2708 & 385 & 256 & 196 & 28 & 53 & 60 & 7 & 149 \\
\hline Qinghai & Northwest & 36 & 93 & 534 & 113 & 78 & 60 & 8 & 14 & 18 & 2 & 38 \\
\hline Ningxia & Northwest & 303 & 276 & 842 & 204 & 136 & 94 & 15 & 20 & 27 & 5 & 103 \\
\hline Xinjiang & Northwest & 460 & 455 & 3047 & 447 & 305 & 227 & 39 & 62 & 58 & 7 & 176 \\
\hline \multicolumn{2}{|c|}{ Total } & 27714 & 28815 & 187900 & 28746 & 16990 & 12212 & 1667 & 2848 & 4253 & 356 & 10176 \\
\hline
\end{tabular}

of precalciner kilns, while helping to control emissions of other pollutants, actually worsened the $\mathrm{NO}_{\mathrm{x}}$ problem. The implementation of staged emission regulation of on-road vehicles could not keep pace with rapid growth of vehicle populations in recent years, and thus failed to prevent emissions from rising overall in this subsector. Moreover, $\mathrm{NO}_{\mathrm{x}}$ emissions from residential combustion of fossil fuels also went up despite decreased coal consumption of that sector, although the share remained small. This resulted mainly from rising use of liquid and natural gas fuels, which emit much less $\mathrm{SO}_{2}$ and particles than coal combustion but relatively more $\mathrm{NO}_{\mathrm{x}}$. All of these facts suggest that $\mathrm{NO}_{\mathrm{x}}$ emission control will be a huge challenge for China in upcoming years. Regarding CO, a much reduced growth rate was found for 2005-2010, reflecting the benefits of improved energy efficiency in recent years (Fig. 3c).

As shown in Fig. $3 d-j$, the emissions of PM of different sizes and chemical species are estimated to have declined to varied extent, and $\mathrm{Ca}$ is the species with biggest emission abatement, by $25 \%$ from 2005 to 2010 . Attributed to the penetration of improved production technologies and dust collectors, national emissions of TSP are estimated to have decreased from 33.2 Mt in 2005 to $28.7 \mathrm{Mt}$ in 2010, of $\mathrm{PM}_{10}$ from 18.9 to $17.0 \mathrm{Mt}$, and of $\mathrm{PM}_{2.5}$ from 13.0 to $12.2 \mathrm{Mt}$. Emission control in cement production is found to have been highly effective, with PM emissions of different sizes and chemical species reduced around $50 \%$. The cement-making share of total emissions decreased from $22 \%$ to $13 \%$ for TSP and from $52 \%$ to $34 \%$ for Ca. In contrast, emissions of different PM categories from iron and steel plants are estimated to have increased $24 \%-39 \%$ from 2005 to 2010 , attributed mainly to huge growth of steel production. The annual variations of national emissions of primary carbonaceous aerosols ranged less than $10 \%$, and the source contributions were relatively stable. The combustion of fossil fuel and biofuel/biomass in residential and commercial activities 


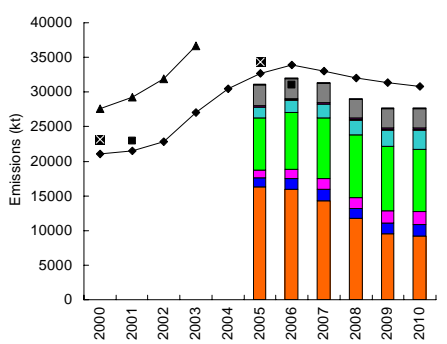

(a) $\mathrm{SO}_{2}$

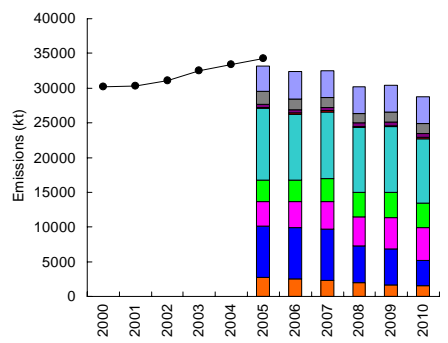

(d) TSP

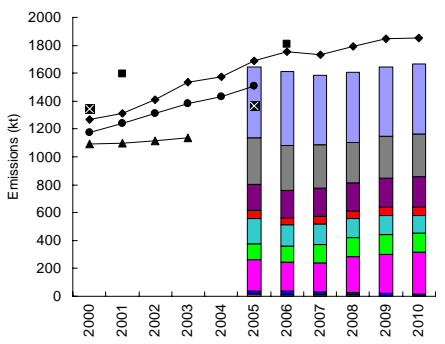

(g) $\mathrm{BC}$

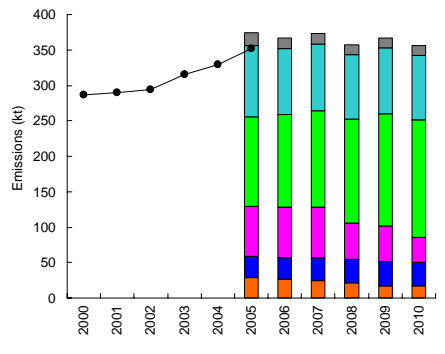

(j) $\mathrm{Mg}$

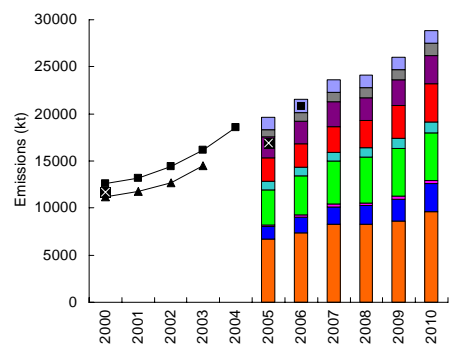

(b) $\mathrm{NO}_{\mathrm{X}}$

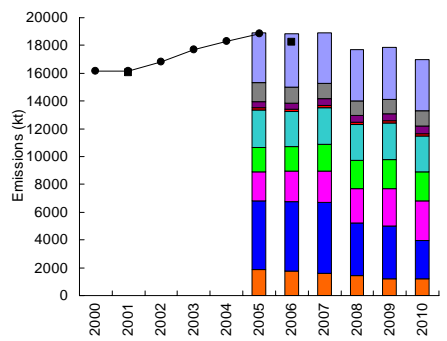

(e) $\mathrm{PM}_{10}$

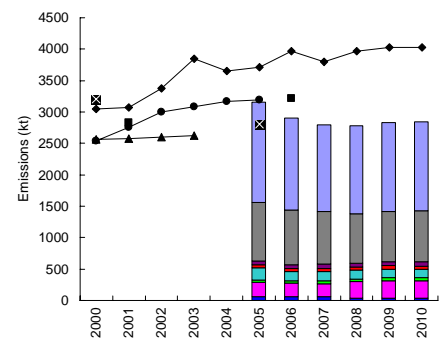

(h) OC

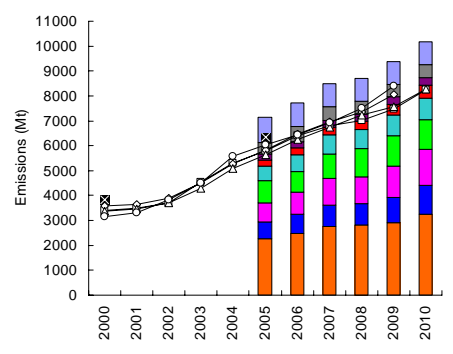

(k) $\mathrm{CO}_{2}$

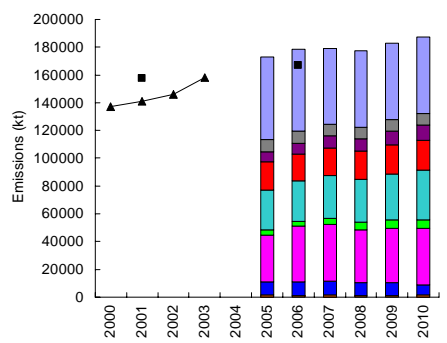

(c) $\mathrm{CO}$

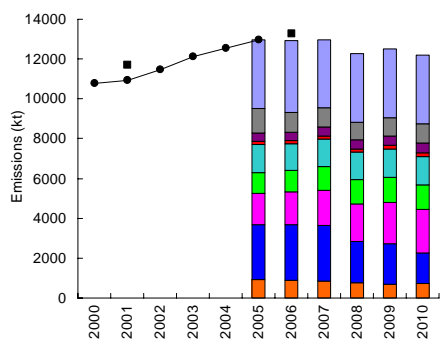

(f) $\mathrm{PM}_{2.5}$

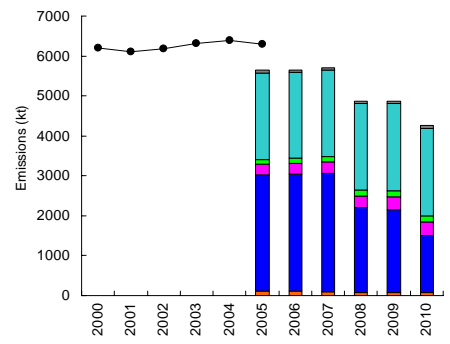

(i) $\mathrm{Ca}$

Other studies

- Klimont et al.(2009); GAINS $\quad-$ - CDIAC

\$- Ohara et al.(2007) -O-USEIA

-Zhang et al.(2007; 2009) $\leadsto$ PBL

- Lei et al (2011a)

- Lu et al.(2011)

This work

$\square$ Residential \& commercial (Biofuel/biomass)

- Residential \& commercial (fossil fuel)

- Non-road transportation

- On-road transportation

Other industrial processe

- Iron \& steel production

- Cement production
a Coal-fired power plants

Fig. 3. The annual emissions by sector in China from 2005 to 2010 as well as total emissions from other studies $2000-2010$.

accounted respectively for around $19 \%$ and $30 \%$ for $\mathrm{BC}$ emissions, and $29 \%$ and $50 \%$ for OC emissions.

$\mathrm{CO}_{2}$ emissions are estimated to have increased from $7126 \mathrm{Mt}$ in 2005 to $10174 \mathrm{Mt}$ in 2010, with an annual growth rate of $7.4 \%$ (Fig. 3k). These totals include emissions from biofuel/ biomass burning, which are omitted in many $\mathrm{CO}_{2}$ inventories. Regarding sector distributions, emissions from power plants, industry, and transportation increased by $44 \%$, $60 \%$, and $64 \%$ during 2005-2010, and the three sectors accounted for $32 \%, 41 \%$, and $8 \%$ of national total emissions in 2010, respectively. Emissions from residential and commercial activities declined slightly.
Provided in Table 1 are the emissions of different species at the provincial level in 2010. The developed regions of east, north-central, and south-central China (as defined in Table 1 and illustrated in Fig. S2 in the Supplement) are estimated to account together for around $70 \%$ of total national emissions of all concerned species in 2010. Notably, the $\mathrm{SO}_{2}$ emissions in north-central and east China declined by $12 \%$ and $20 \%$ respectively during 2005-2010, indicating considerable achievements of emission control in these heavily polluted regions. The analogous reductions for northeast and southwest China, however, are merely $2 \%$. In the northeast, where coals with low sulfur content (such as lignite) are widely used, the $\mathrm{SO}_{2}$ emissions from coal combustion 
were relatively small and thus there is less need for FGD at existing power units than in other areas. In contrast, the sulfur content of coals in the southwest are extremely high and many power units had FGD already installed by 2005, leading to limited potential for further reduction of emissions after 2005. Among all the regions, the northwest had the fastest growth of $\mathrm{NO}_{\mathrm{x}}$ and $\mathrm{CO}_{2}$ emissions, indicating a relatively rapid increase of economic activity and energy consumption in that less-developed area, although its shares of total national emissions remained small.

\subsection{Comparisons with other studies}

Figure 3 also shows national emission trends estimated by other studies for different species since 2000. Only studies with emissions for multiple years are selected for comparison with current results. Along with $\mathrm{CO}_{2}, \mathrm{CO}$ and $\mathrm{NO}_{\mathrm{x}}$ are the species with monotonic emission increases during 2000 2010. Ohara et al. (2007) estimated an average annual growth of $4.9 \%$ for CO from 2000 to 2003, while the value for 20052010 indicated by this work is $1.6 \%$, reflecting improved energy efficiency and emission control of $\mathrm{CO}$ after 2005. For $\mathrm{NO}_{\mathrm{x}}$, Zhang et al. (2007) and Ohara et al. (2007) estimated average annual growth rates of $10.2 \%$ and $8.9 \%$ for 2000 2004 and 2000-2003, respectively, close to $8.0 \%$ for 2005 2010 by this work, suggesting limited overall effectiveness of $\mathrm{NO}_{\mathrm{x}}$ abatement policies to date.

For $\mathrm{SO}_{2}$ and $\mathrm{PM}$ of different size classes, combining results of other studies and this work shows that the growth of emissions in the early-2000s have been gradually reversed in recent years. Generally consistent trends of $\mathrm{SO}_{2}$ emissions from 2005 to 2010 were indicated by Lu et al. (2011) and this work, although the current estimates are consistently lower. The discrepancy is likely attributable mainly to applications of different FGD removal efficiencies in the two studies. Lacking estimates in more recent years for comparison, the emissions of TSP, $\mathrm{PM}_{10}$, and $\mathrm{PM}_{2.5}$ for 2005 in Lei et al. (2011a) and this work are close. Regarding chemical species, however, the different studies are relatively inconsistent. For example, decreasing trends of carbonaceous aerosol emissions were given by Klimont et al. (2009) for 20002005, while increasing trends were suggested by other studies. Even with similar inter-annual trends, Zhang et al. (2009) estimated higher BC emissions from 2001 to 2006 than Lu et al. (2011), but much lower OC. The carbonaceous aerosol emissions estimated by this work are close to or higher than those of Klimont et al. (2009) and Lei et al. (2011a), but clearly lower than those of Lu et al. (2011). Although Lu et al. (2011) included emissions from burning of forest and savanna that is omitted by this work, the contribution of that source was very small and cannot fully explain the differences. The divergent results indicate large uncertainties for estimates of emissions of chemical species of PM, particularly from the burning of fossil fuel and biofuel/biomass in residential activities, helping to motivate the uncertainty analysis of bottom-up emissions described in Sect. 4.3.

Compared to gaseous and PM pollutants, the disparities in $\mathrm{CO}_{2}$ emissions between different studies are smaller, as shown in Fig. 3k. Note the results of other studies and this work for total $\mathrm{CO}_{2}$ emissions cannot be directly compared because the emissions estimated by the US Carbon Dioxide Information Analysis Center (CDIAC, http://cdiac.ornl.gov/ftp/trends/emissions/), the PBL Netherlands Environmental Assessment Agency (PBL, http://www. pbl.nl/sites/default/files/cms/publicaties/500212001.pdf), the US Energy Information Administration (USEIA, http://www.eia.gov/cfapps/ipdbproject/IEDIndex3.cfm?tid= 90\&pid=44\&aid=8), and the International Energy Agency (IEA, http://www.iea.org/publications/freepublications/ publication/name,4010, en.html) include only those from fossil fuel combustion and sometimes cement production, while this work also includes emissions from other non-combustion industrial processes and biofuel/biomass burning (see details in Zhao et al., 2012b). (Note that USEIA and IEA do not report cement process emissions, and the estimates by CDIAC are added to USEIA and IEA fossil fuel emissions in Fig. 3k to facilitate some comparison of the studies by equivalent inclusion of source types.) Even excluding the emissions from biomass/biofuel, discrepancy remains between this work and other studies. The $\mathrm{CO}_{2}$ emissions for 2005-2010 estimated by us are generally higher than those by most of other studies, attributed mainly to the application of a domestic $\mathrm{CO}_{2}$ emission factor database (Zhao et al., 2012b), and the use of provincial-level energy data in this work, as confirmed by Guan et al. (2012). Moreover, the non-combustion $\mathrm{CO}_{2}$ emissions from industrial processes, such as the emissions from primary aluminum production due to the consumption of carbon anodes in the reaction to convert aluminum oxide to aluminum metal, are also included in this work, although the amount from those sources is relatively small. From 2000 to 2005, the annual growth rates of $\mathrm{CO}_{2}$ emissions from fossil fuel combustion plus cement production are estimated to have ranged from $10.2 \%$ by PBL to $13.9 \%$ by USEIA, while growth in annual emissions declined to $8.5 \%$ from 2005 to 2010 based on the current study. This suggests the effects both of slowed economic development and of improved energy efficiency for the country during 2005-2010.

\subsection{Uncertainty analysis of emissions in $\mathbf{2 0 1 0}$}

The uncertainties of emissions for different species in 2010 are estimated using a Monte-Carlo framework developed by Zhao et al. (2011a). The principles of determining the uncertainties of all the parameters, expressed as the probability distribution function (PDF), were described in detail by Zhao et al. (2011a, 2012a, b). With updated PDFs for 2010, a total of 10000 simulations are performed and the uncertainties of emissions, expressed as $95 \%$ confidence intervals 
Table 2. Uncertainties of Chinese emissions by sector in 2010. The emissions are expressed as $\mathrm{Mt}_{\mathrm{t}}$ for $\mathrm{CO}_{2}$ and $\mathrm{kt}$ for other species. The percentages in the parentheses indicate the $95 \% \mathrm{CI}$ around the central estimate.

\begin{tabular}{llllll}
\hline & Power plants & Total industry & Transportation & Residential and commercial & Total \\
\hline $\mathrm{SO}_{2}$ & $9199(-27 \%, 59 \%)$ & $15254(-22 \%, 27 \%)$ & $374(-21 \%, 41 \%)$ & $2888(-46 \%, 51 \%)$ & $27714(-15 \%, 26 \%)$ \\
$\mathrm{NO}_{\mathrm{x}}$ & $9629(-19 \%, 15 \%)$ & $9541(-32 \%, 90 \%)$ & $7042(-30 \%, 56 \%)$ & $2604(-37 \%, 101 \%)$ & $28815(-15 \%, 35 \%)$ \\
$\mathrm{CO}$ & $1400(-27 \%, 38 \%)$ & $90058(-11 \%, 31 \%)$ & $32676(-44 \%, 74 \%)$ & $63765(-49 \%, 101 \%)$ & $187900(-18 \%, 42 \%)$ \\
$\mathrm{TSP}$ & $1592(-22 \%, 37 \%)$ & $21141(-28 \%, 65 \%)$ & $727(-29 \%, 47 \%)$ & $5285(-51 \%, 91 \%)$ & $28746(-22 \%, 54 \%)$ \\
$\mathrm{PM}_{10}$ & $1233(-25 \%, 43 \%)$ & $10254(-16 \%, 69 \%)$ & $709(-29 \%, 49 \%)$ & $4794(-53 \%, 98 \%)$ & $16990(-15 \%, 54 \%)$ \\
$\mathrm{PM}_{2.5}$ & $717(-34 \%, 62 \%)$ & $6394(-15 \%, 85 \%)$ & $672(-30 \%, 50 \%)$ & $4429(-54 \%, 99 \%)$ & $12212(-15 \%, 63 \%)$ \\
$\mathrm{BC}$ & $5(-68 \%, 574 \%)$ & $574(-49 \%, 117 \%)$ & $279(-71 \%, 77 \%)$ & $809(-53 \%, 240 \%)$ & $1667(-28 \%, 126 \%)$ \\
$\mathrm{OC}$ & $0(-76 \%, 2373 \%)$ & $493(-41 \%, 141 \%)$ & $127(-68 \%, 86 \%)$ & $2228(-57 \%, 136 \%)$ & $2848(-42 \%, 114 \%)$ \\
$\mathrm{Ca}$ & $69(-28 \%, 45 \%)$ & $4119(-78 \%, 77 \%)$ & - & $65(-74 \%, 219 \%)$ & $4253(-75 \%, 77 \%)$ \\
$\mathrm{Mg}$ & $17(-26 \%, 37 \%)$ & $325(-52 \%, 37 \%)$ & - & $14(-75 \%, 193 \%)$ & $356(-46 \%, 152 \%)$ \\
$\mathrm{CO}$ & $3253(-13 \%, 14 \%)$ & $4635(-14 \%, 17 \%)$ & $834(-12 \%, 16 \%)$ & $1454(-37 \%, 20 \%)$ & $10176(-10 \%, 9 \%)$ \\
\hline
\end{tabular}

Table 3. The top two parameters contributing most to emission uncertainties by sector for 2010. The percentages in the parentheses indicate the contributions of the parameters to the variances of emissions (see Eq. (1) for the abbreviations of parameters).

\begin{tabular}{|c|c|c|c|c|}
\hline & Coal-fired power plants & Total industry & Transportation & Residential and commercial activity \\
\hline \multirow[t]{2}{*}{$\mathrm{SO}_{2}$} & $\eta_{\mathrm{SO} 2, \mathrm{FGD}}(72 \%)$ & $\mathrm{SR}_{\text {grate boiler }}^{1}(22 \%)$ & $\mathrm{SR}_{\text {non-road coal combustion }}(43 \%)$ & $\mathrm{EF}_{\mathrm{SO} 2, \text { hot water system }}(38 \%)$ \\
\hline & $\mathrm{AL}_{\text {coal }}(5 \%)$ & $\mathrm{AL}_{\text {coal }}(19 \%)$ & $\mathrm{AL}_{\text {non-road source, coal }}(29 \%)$ & $\mathrm{AL}_{\text {coal }}(37 \%)$ \\
\hline \multirow{2}{*}{$\mathrm{NO}_{\mathrm{x}}$} & $\mathrm{EF}_{\mathrm{NOx}}$ tangential bituminous boiler $(28 \%)$ & $\mathrm{EF}_{\mathrm{NOx}}$, grate boiler $(74 \%)$ & $\mathrm{EF}_{\mathrm{NOx}}$, inland ship $(54 \%)$ & $\mathrm{EF}_{\mathrm{NOx}}$, oil $(45 \%)$ \\
\hline & $\mathrm{AL}_{\text {coal }}(27 \%)$ & $\mathrm{EF}_{\mathrm{NOx}}$, precalciner cement kiln $(9 \%)$ & $\mathrm{AL}_{\mathrm{HDDV}, \text { Diesel }}(8 \%)$ & $\mathrm{EF}_{\mathrm{NOx}}$, biomass open burning $(14 \%)$ \\
\hline \multirow{2}{*}{$\mathrm{CO}$} & $\mathrm{EF}_{\mathrm{CO}}$, pulverized boilers (<200MW) $(41 \%)$ & $\mathrm{EF}_{\mathrm{CO}, \text { refinery }}(36 \%)$ & $\mathrm{EF}_{\mathrm{CO}, \text { small gasoline engine }}(24 \%)$ & $\mathrm{EF}_{\mathrm{CO}, \text { straw as biofuel }}(64 \%)$ \\
\hline & $\mathrm{EF}_{\mathrm{CO}}$, pulverized boilers $(\geq 200 \mathrm{MW})(28 \%)$ & $\mathrm{EF}_{\mathrm{CO}}$, brick making $(14 \%)$ & $R_{\text {LDGV, Stage III }}(13 \%)$ & $\mathrm{AL}_{\text {biofuel, straw }}(19 \%)$ \\
\hline \multirow{2}{*}{ TSP } & $f_{\mathrm{PM} 2.5, \text { pulverized boiler }}^{2}(28 \%)$ & $R_{\text {lime production, cyclone }}(26 \%)$ & $\mathrm{EF}_{\mathrm{PM} 2.5, \text { rural machine }}(38 \%)$ & $\mathrm{EF}_{\mathrm{PM} 2.5, \text { straw as biofuel }}(42 \%)$ \\
\hline & $\mathrm{AL}_{\text {coal }}(11 \%)$ & $R_{\text {lime production, ESP }}(15 \%)$ & $\mathrm{EF}_{\mathrm{PM} 2.5 \text {, construction machine }}(15 \%)$ & $\mathrm{EF}_{\mathrm{TSP}}$, coal stove $(19 \%)$ \\
\hline \multirow{2}{*}{$\mathrm{PM}_{10}$} & $f_{\mathrm{PM} 2.5, \text { pulverized boiler }}(37 \%)$ & $\mathrm{AR}_{\text {grate boiler }}^{3}(12 \%)$ & $\mathrm{EF}_{\mathrm{PM} 2.5, \text { rural machine }}(39 \%)$ & $\mathrm{EF}_{\mathrm{PM} 2.5, \text { straw as biofuel }}(43 \%)$ \\
\hline & $\eta_{\mathrm{PM} 2.5, \mathrm{ESP}}(13 \%)$ & $\mathrm{EF}_{\mathrm{TSP}}$, precalciner cement kiln $(10 \%)$ & $\mathrm{EF}_{\mathrm{PM} 2.5, \text { construction machine }}(16 \%)$ & $\mathrm{EF}_{\mathrm{TSP}}$, coal stove $(21 \%)$ \\
\hline \multirow{2}{*}{$\mathrm{PM}_{2.5}$} & $f_{\mathrm{PM} 2.5 \text {, pulverized boiler }}(55 \%)$ & $f_{\mathrm{PM} 2.5, \text { grate boiler }}(17 \%)$ & $\mathrm{EF}_{\mathrm{PM} 2.5, \text { rural machine }}(41 \%)$ & $\mathrm{EF}_{\mathrm{PM} 2.5, \text { straw as biofuel }}(42 \%)$ \\
\hline & $\eta_{\mathrm{PM} 2.5, \mathrm{ESP}}(19 \%)$ & $\mathrm{AR}_{\text {grate boiler }}(12 \%)$ & $\mathrm{EF}_{\mathrm{PM} 2.5, \text { construction machine }}(16 \%)$ & $\mathrm{EF}_{\mathrm{TSP}, \text { coal stove }}(21 \%)$ \\
\hline \multirow{2}{*}{$\mathrm{BC}$} & $F_{\mathrm{BC}, \text { pulverized boiler }}^{4}(79 \%)$ & $\mathrm{AL}_{\text {coke production }}(26 \%)$ & $F_{\mathrm{BC}, \text { non-road coal combustion }}(76 \%)$ & $\mathrm{EF}_{\mathrm{BC}, \text { coal stove }}(58 \%)$ \\
\hline & $f_{\mathrm{PM} 2.5, \text { pulverized boiler }}(5 \%)$ & $F_{\mathrm{BC}, \text { grate boiler }}(15 \%)$ & $\mathrm{EF}(8 \%)$ & $\mathrm{EF}_{\mathrm{BC}, \text { straw as biofuel }}(18 \%)$ \\
\hline \multirow{2}{*}{$\mathrm{OC}$} & $F_{\mathrm{OC}, \text { grate boiler }}(42 \%)$ & $\mathrm{AL}_{\text {coke production }}(24 \%)$ & $F_{\mathrm{OC}, \text { non-road coal combustion }}(53 \%)$ & $\mathrm{EF}_{\mathrm{OC}, \text { coal stove }}(40 \%)$ \\
\hline & $f_{\mathrm{PM} 2.5 \text {, grate boiler }}(24 \%)$ & $F_{\mathrm{OC}, \text { grate boiler }}(17 \%)$ & $F_{\mathrm{OC}, \text { on }- \text { road diesel vehicle }}(25 \%)$ & $\mathrm{EF}_{\mathrm{OC}}$, straw as biofuel $(24 \%)$ \\
\hline \multirow{2}{*}{$\mathrm{Ca}$} & $f_{\mathrm{PM} 2.5, \text { pulverized boiler }}(18 \%)$ & $R_{\text {lime production, cyclone }}(40 \%)$ & - & $\mathrm{EF}_{\mathrm{TSP}}$, coal stove $(78 \%)$ \\
\hline & $\eta_{\mathrm{PM} 2.5, \text { ESP }}(7 \%)$ & $R_{\text {lime production, ESP }}(23 \%)$ & - & ALcoal $(11 \%)$ \\
\hline \multirow{2}{*}{$\mathrm{Mg}$} & $f_{\mathrm{PM} 2.5, \text { pulverized boiler }}(24 \%)$ & $F_{\mathrm{Mg}, \text { iron and steel production }}(60 \%)$ & - & $\mathrm{EF}_{\mathrm{TSP}, \text { coal stove }}(80 \%)$ \\
\hline & $\mathrm{AL}_{\text {coal }}(9 \%)$ & $R_{\text {iron an steel production cyclone }}(12 \%)$ & - & $\mathrm{AL}_{\text {coal }}(11 \%)$ \\
\hline \multirow{2}{*}{$\mathrm{CO}_{2}$} & $\mathrm{AL}_{\text {coal }}(53 \%)$ & $\mathrm{EF}_{\mathrm{CO} 2 \text {, bituminous boiler }(42 \%)}$ & $\mathrm{AL}_{\text {LDGV, gasoline }}(30 \%)$ & $\mathrm{AL}_{\text {biofuel, straw }}(38 \%)$ \\
\hline & $\mathrm{EF}_{\mathrm{CO} 2 \text {, bituminous boiler }}(43 \%)$ & $\mathrm{EF}_{\mathrm{CO} 2, \text { iron steel production }}(31 \%)$ & $\mathrm{AL}_{\mathrm{HDDV}}$, diesel $(18 \%)$ & $\mathrm{EF}_{\mathrm{CO} 2 \text {, straw as biofuel }}(21 \%)$ \\
\hline
\end{tabular}

${ }^{1} \mathrm{SR}$, the release ratio of sulfur content during combustion; ${ }^{2} f$, the mass fraction of particles with specific size to TSP; ${ }^{3}$ AR, the release ratio of ash content during combustion;

${ }^{4} F$, the mass fraction of chemical species to $\mathrm{PM}_{2.5}$ (for carbonaceous aerosols) or TSP (for base cations).

(CIs) around the central estimates, are generated by sector and species, as shown in Table 2. The parameters most significant in determining the uncertainties of emissions, judged by their contribution to the variance, are also identified by the Monte-Carlo simulations and are shown in Table 3.

The uncertainties of China's anthropogenic emissions of gaseous pollutants $\mathrm{SO}_{2}, \mathrm{NO}_{\mathrm{x}}$, and $\mathrm{CO}$ in 2010 are estimated to be $-15 \%$ to $+26 \%,-15 \%$ to $+35 \%$, and $-18 \%$ to $+42 \%$, respectively; those for primary aerosols TSP, $\mathrm{PM}_{10}$, $\mathrm{PM}_{2.5}, \mathrm{BC}, \mathrm{OC}, \mathrm{Ca}$, and $\mathrm{Mg}$ are $-22 \%$ to $+54 \%,-15 \%$ to $+54 \%,-15 \%$ to $+63 \%,-28 \%$ to $+126 \%,-42 \%$ to $+114 \%,-75 \%$ to $+77 \%$, and $-46 \%$ to $+152 \%$, respectively; and that of the greenhouse gas $\mathrm{CO}_{2}$ is $-10 \%$ to $+9 \%$. In general the results of the uncertainty analyses are similar to those for 2005 (Zhao et al., 2011a, 2012a, b) in that: (1) the uncertainties of emissions of gaseous pollutants are smaller than those of primary aerosols; (2) among sectors, the uncertainties associated with residential and commercial activities are the largest; and (3) in most cases, parameters related with emission factors contribute most to the uncertainties of 


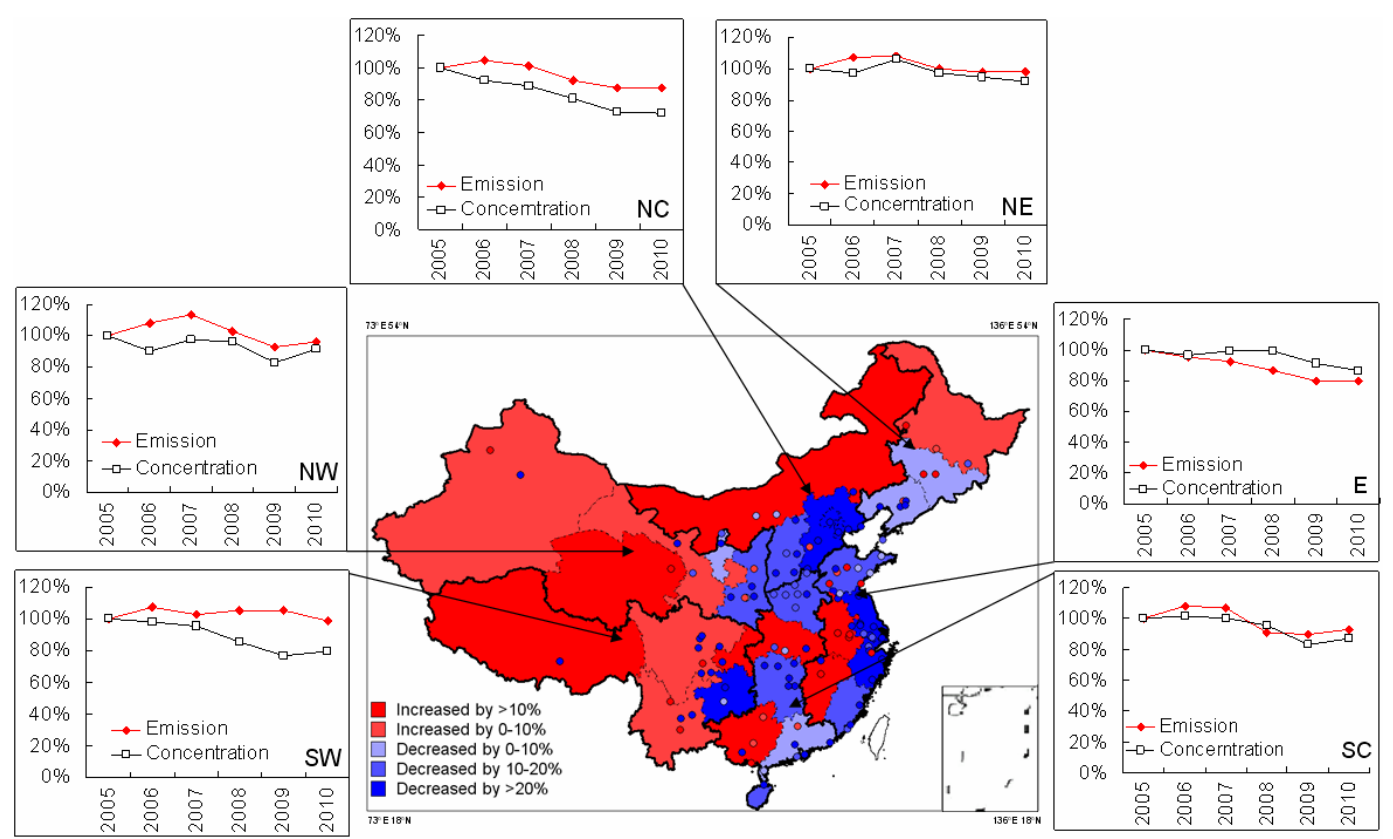

(a) $\mathrm{SO}_{2}$

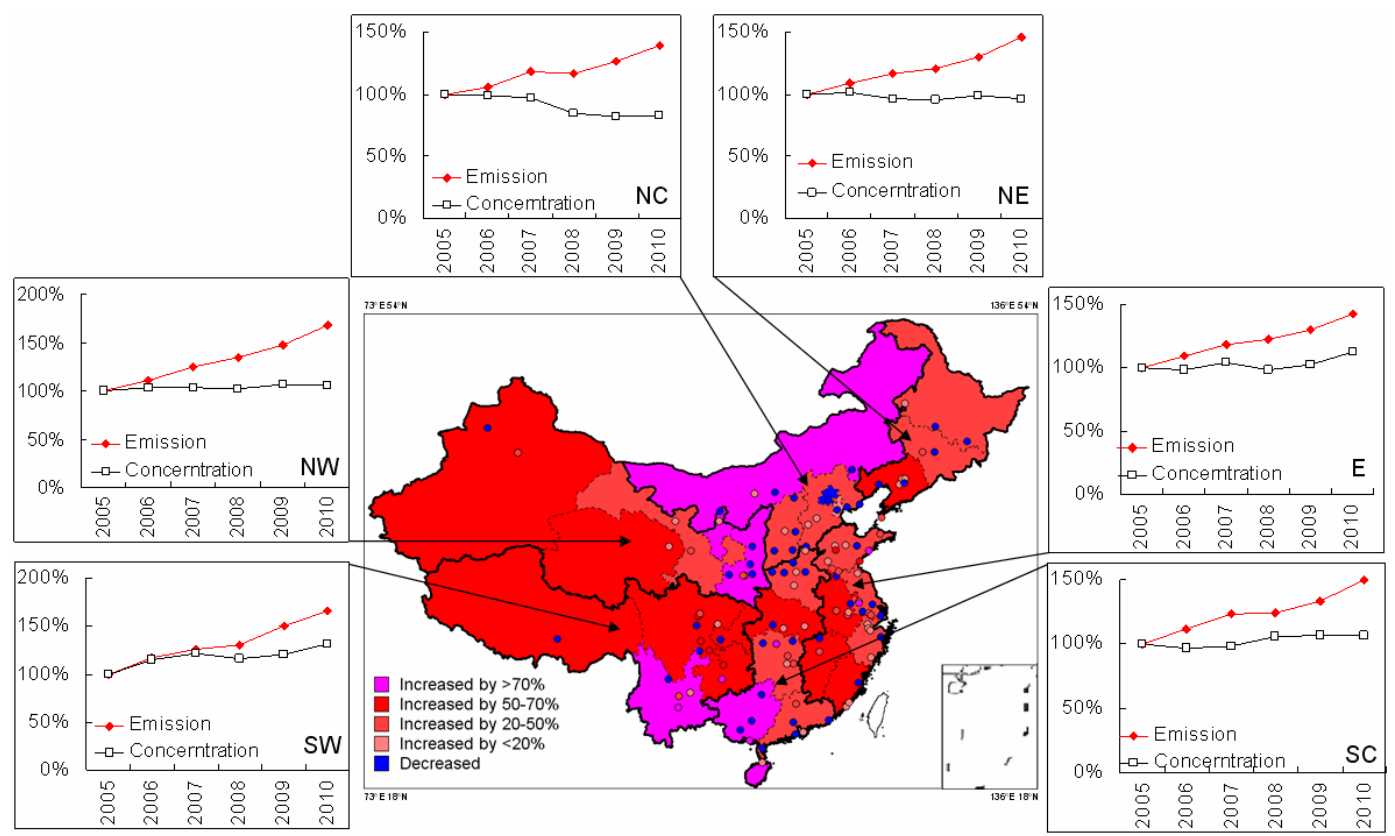

(b) $\mathrm{NO}_{2}$ (for concentration) $/ \mathrm{NO}_{\mathrm{X}}$ (for emission)

Fig. 4. Inter-annual trends of the average ambient concentrations for $113 \mathrm{key}$ cities reported by MEP and emissions estimated by this work. The maps illustrate the changes in emissions by province and concentrations by city between 2005 and 2010 . The panels around the maps illustrate the relative changes in emissions by region and concentrations by city from 2005 to 2010 . Thick lines in the maps indicate borders of the six regions: North-central China (NC), Northeast China (NE), East China (E), South-central China (SC), Southwest China (SW), and Northwest China (NW).

atmospheric pollutants, while activity levels are more significant to uncertainties of $\mathrm{CO}_{2}$, except for the industry sector (Table 3).
Some of the estimated uncertainties for given sectors and species change significantly from 2005 to 2010 . First, the uncertainty of $\mathrm{SO}_{2}$ emissions from power plants rises from $-16 \%$ to $+21 \%$ in 2005 to $-27 \%$ to $+59 \%$ in 2010 . 


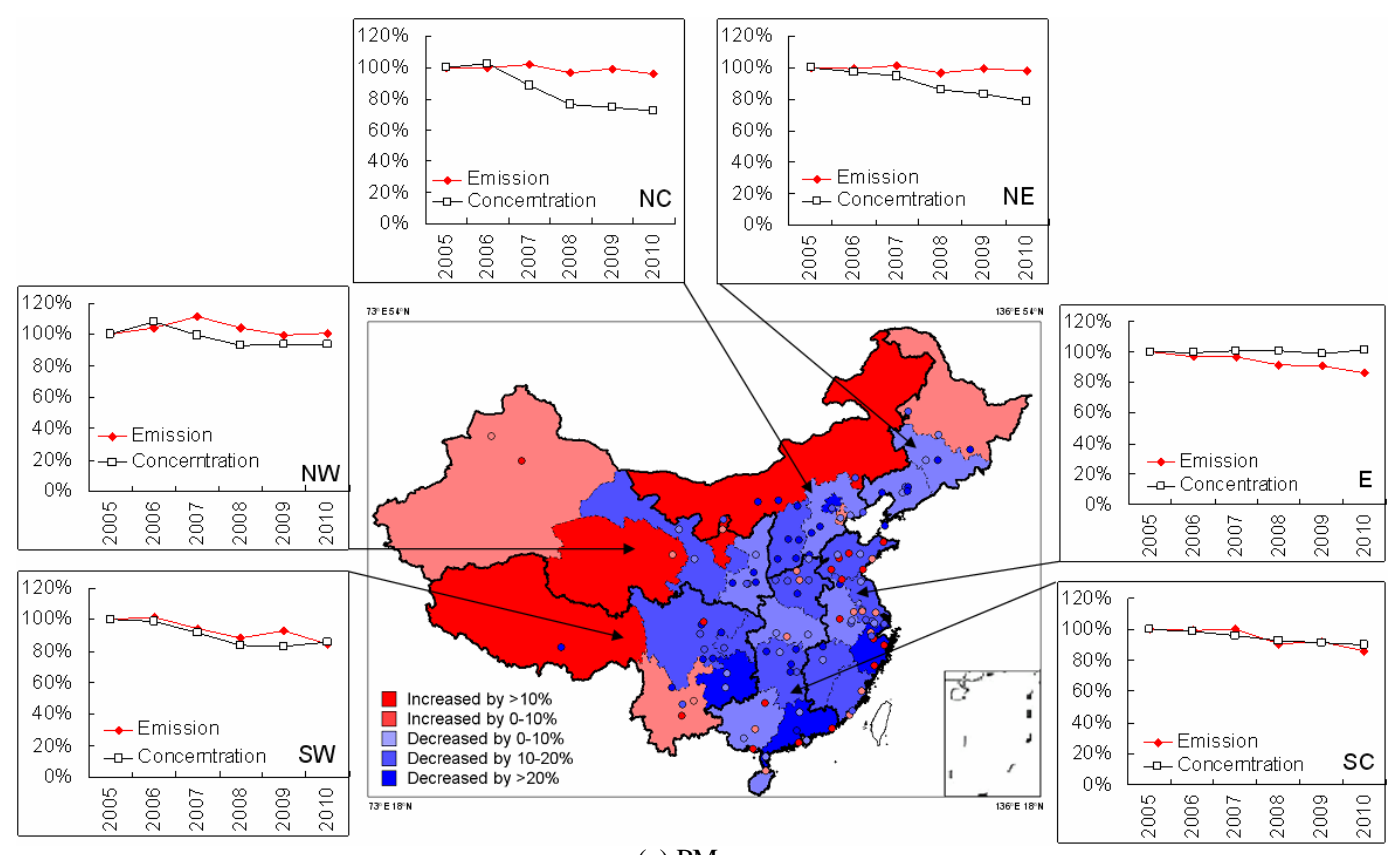

(c) $\mathrm{PM}_{10}$

Fig. 4. Continued.

The uncertainty of total national $\mathrm{SO}_{2}$ emissions is accordingly larger in 2010 , at $-15 \%$ to $+26 \%$, than that in 2005 , at $-14 \%$ to $+13 \%$. This results mainly from the swift penetration of FGD systems, of which the $\mathrm{SO}_{2}$ removal efficiency may vary nationally and is poorly quantified. Although designed FGD removal efficiencies can reach $95 \%$, the installed FGD systems are not believed to have achieved such high values because they were not always operated fully (Xu et al., 2009; Xu, 2011). FGD systems operated less consistently than expected reduces the anticipated benefits of $\mathrm{SO}_{2}$ emission control on power plants, and increases the uncertainty of the $\mathrm{SO}_{2}$ emission inventory for recent years as well. As shown in Table 3, the removal efficiency of FGD contributed $72 \%$ to the variance of $\mathrm{SO}_{2}$ emissions from power plants, and more investigations are thus necessary to better quantify typical removal efficiencies of FGD systems. Second, the uncertainties of $\mathrm{NO}_{\mathrm{x}}$ and $\mathrm{PM}$ emissions from transportation declined from 2005 to 2010. As staged emissions regulations of vehicles have been implemented since 2005 , more measurements on the emission factors of onroad and rural vehicles designed for different control standards have been conducted and reported (e.g., He et al., 2010; Wu et al., 2012). The increased sampling sizes and improved measurement methods of those studies have helped considerably to reduce the uncertainties of vehicle emission factors. Third, the uncertainties of PM emissions of different particle size classes have increased, particularly for TSP. This is attributed mainly to penetration levels of dust collectors for given industrial processes during 2005-2010 that must be assumed, without sufficient field data. As shown in Table 3, the penetration level of dust collectors for lime production is the most significant parameter contributing to the uncertainty of TSP emissions from the industry sector for 2010, while the analogous parameters for 2005 are the emission factors for non-combustion cement processing and grate boiler combustion (Zhao et al., 2011a). Compared to fine particles, the uncertainty of TSP emissions increased more significantly, reaching $-22 \%$ to $+54 \%$ in 2010 , exceeding that of $\mathrm{PM}_{10}$. If no technology improvement of dust collectors is assumed for industrial processes, as described in Sect. 3.5, the national TSP emissions are reestimated at $39.6 \mathrm{Mt}$, i.e., $38 \%$ higher than the original estimate. The analogous values for $\mathrm{PM}_{10}$ and $\mathrm{PM}_{2.5}$ would be $16 \%$ and $12 \%$ higher, respectively, much smaller than that of TSP; and those for BC and OC less than $5 \%$. These results indicate that the uncertainty of dust collector penetrations in industrial sources have fewer impacts on emission estimates for fine particles and carbonaceous aerosols than for TSP. The benefits of those technologies on PM control are particularly from certain industrial sources with relatively large emission fractions of coarse particles including lime and brick production, as indicated in Klimont et al. (2002).

\subsection{Comparisons with ground observation}

The inter-annual trends of emissions are compared with those derived from observations. During the study period, $\mathrm{SO}_{2}$, $\mathrm{NO}_{2}$, and $\mathrm{PM}_{10}$ were criteria pollutants for which concentrations were reported for 113 "key" cities by the Ministry of Environmental Protection (MEP) of China, based on their 
large populations, developed economies, and/or heavy pollution levels. Figure 4 shows comparisons of relative interannual variations between the estimated emissions and the reported concentrations of monitored cities (compiled from the datasets available at: http://datacenter.mep.gov.cn/) by region from 2005 to 2010, normalized to 2005 levels. The maps illustrate the changes in emissions for provinces and concentrations for cities, while the panels around the maps illustrate the trends in emissions for broader regions (as defined in Table 1) and concentrations for cities in those regions.

The inter-annual trends of emissions and observed concentrations are generally consistent with each other, although there are also some discrepancies for given species and regions. For $\mathrm{SO}_{2}$, as shown in Fig. 4a, similar declining trends for emissions and concentrations are found for north-central, northeast, east, and south-central China between 2005 and 2010, confirming the effects of national policy on $\mathrm{SO}_{2}$ control. However, increased $\mathrm{SO}_{2}$ concentrations are found for several cities in east China while decreased provincial emissions are estimated. This is possibly because (1) some local sources like small coal stoves which are missed in the energy statistics and thus omitted in the emission inventory framework grew in recent years; and/or (2) the operation of FGD was actually poorer than expected in some specific areas. In contrast, decreased concentrations were observed with increased emissions between 2005 and 2010 for some provinces in southwest China. As discussed in Sect. 4.1, the limited potential expansion of FGD for power plants in the region could not significantly reduce $\mathrm{SO}_{2}$. The declining concentrations thus imply that some local measures of $\mathrm{SO}_{2}$ control, such as coal washing, may not be well characterized by this work. The disagreements of emission and concentration trends in certain areas indicate the pressing needs of more detailed local investigations on emission characteristics and control measures.

As shown in Fig. 4b, $\mathrm{NO}_{\mathrm{x}}$ emissions are estimated to have increased much faster than $\mathrm{NO}_{2}$ concentrations from 2005 to 2010 in all regions. Indeed decreased urban average $\mathrm{NO}_{2}$ concentrations were reported in north-central and northeast China, shown in the line plots for those regions. The relatively large gaps between regional emissions and observed urban concentrations likely reflect that $\mathrm{NO}_{\mathrm{x}}$ (the estimated emission species) includes $\mathrm{NO}$ as well as $\mathrm{NO}_{2}$ (the observed concentration species). Complex local $\mathrm{NO}_{\mathrm{x}}$ sources contributed higher levels of NO in urban areas than rural or remote ones, though it is omitted in measurements of urban $\mathrm{NO}_{2}$ concentrations. Satellite observation at larger spatial scales will be used to further examine the inter-annual trends of estimated emissions, as described in Sect. 4.5.

The inter-annual trends of emissions and concentrations for $\mathrm{PM}_{10}$ match well for most regions, as shown in Fig. 4c. In north-central China, faster reduction of urban $\mathrm{PM}_{10}$ concentrations is found than that of estimated provincial emissions. This is probably attributable to gradually implemented control measures (e.g., road paving and afforestation) on fugi- tive dust from construction sites, unpaved roads, or natural sources. These are not included in the current emission inventory. Similar to $\mathrm{SO}_{2}$, there are some cities in east China with increased observed $\mathrm{PM}_{10}$ concentrations despite estimated declines in regional emissions from 2005 to 2010, suggesting that some local small industrial and/or residential sources, which generate PM emissions from coal or biomass combustion, probably increased though they are not well accounted for in recent years.

The government has not systematically reported urban concentrations of other species including $\mathrm{BC}, \mathrm{OC}, \mathrm{CO}$, or $\mathrm{CO}_{2}$. As summarized in Table 4, however, a number of independent studies have been conducted in different periods and locations in China to observe ambient BC, $\mathrm{OC}, \mathrm{CO}$, and $\mathrm{CO}_{2}$ levels. Correlation slopes between some of these observed species, e.g., $\mathrm{dBC} / \mathrm{dCO}, \mathrm{dOC} / \mathrm{dBC}$, and $\mathrm{dCO}_{2} / \mathrm{dCO}$, have been estimated to approximate emissions. To test the accuracy of the bottom-up emissions in this work, the ratios of $\mathrm{BC}$ to $\mathrm{CO}$ emissions $\left(\mu \mathrm{g} \mathrm{m}^{-3} \mathrm{ppbv}^{-1}\right.$, note that $1 \mu \mathrm{g} \mathrm{m}^{-3} \mathrm{ppbv}^{-1}=1.25 \mathrm{kt} \mathrm{kt}^{-1}$ ) and those of OC to BC $\left(\mu \mathrm{g} \mathrm{m}^{-3} / \mu \mathrm{g} \mathrm{m}^{-3}\right.$ ) are calculated for the corresponding periods and locations in which the observations were conducted (see also an analysis of $\mathrm{CO}_{2} / \mathrm{CO}$ ratios in Zhao et al., 2012a). Monthly variations of emissions are generated following the methods of Zhang et al. (2009), and are used in the calculation of emission ratios for periods matching the observations. In one case, Andreae et al. (2008), the observations were conducted outside of the study period of this work, in OctoberNovember 2004, so emissions for the corresponding months in 2005 are instead applied here for comparison. The ratios of emissions are determined at two spatial scales: a local scale, based on provincial emissions, and a multi-province regional scale, as defined in Table 1 . One exception to this definition is for the comparison with Kondo et al. (2011), which reported the results of $\mathrm{dBC} / \mathrm{dCO}$ observed at Cape Hedo on Okinawa Island, Japan, representing emissions exported from east China. In this case the local emission ratio is calculated based on emissions in east China while the regional one is based on those for the whole country.

As shown in Table 4, in most cases the BC/CO ratios from estimated emissions are higher than the correlation slopes from observations in China. However, once the influence of wet deposition and atmospheric chemistry processes are excluded (Kondo et al., 2011; Wang et al., 2011), the ratios are much closer to each other, indicating consistency of observations and bottom-up emissions. In all cases, the $\mathrm{BC} / \mathrm{CO}$ emission ratios at regional levels are larger than those at local levels. Since the observations were mainly conducted in or close to developed mega cities, on-road gasoline vehicles which generate elevated $\mathrm{CO}$ contribute more to local emissions than they do at regional scale. The regional emissions include more combustion of residential solid fuels in less developed rural areas, which generate higher BC emissions. Zhou et al. (2009) conducted observations in Beijing (in north-central China) and Taicang (in Jiangsu province, 
Table 4. The ratios of $\mathrm{BC}$ to $\mathrm{CO}\left(\mu \mathrm{g} \mathrm{m}^{-\mathbf{3}} \mathrm{ppbv}^{-1}\right)$ and $\mathrm{OC}$ to $\mathrm{BC}\left(\mu \mathrm{g} \mathrm{m}{ }^{-3} / \mu \mathrm{g} \mathrm{m}^{-3}\right)$ from observations and bottom-up emissions in China.

\begin{tabular}{|c|c|c|c|c|c|}
\hline \multirow{2}{*}{ Sources } & \multirow{2}{*}{ Location } & \multirow{2}{*}{ Period and seasons } & \multirow{2}{*}{$\begin{array}{l}\text { Observed } \\
\text { slopes }\end{array}$} & \multicolumn{2}{|c|}{ Emission ratios } \\
\hline & & & & Local & Regional \\
\hline \multicolumn{6}{|l|}{$\mathrm{BC} / \mathrm{CO}$} \\
\hline Kondo et al. (2011) & Okinawa Island, Japan & Feb 2008-May 2009 & $\begin{array}{l}0.0039^{1} \\
0.0075^{2}\end{array}$ & 0.0099 & 0.0106 \\
\hline Wang et al. (2011) & Miyun, Beijing (rural) & Apr-Oct, 2010 & $\begin{array}{l}0.0046^{1} \\
0.0095^{3}\end{array}$ & 0.0081 & 0.0116 \\
\hline \multirow{4}{*}{ Han et al. (2009) } & \multirow{4}{*}{ PKU, Beijing (urban) } & Nov 2005-Jan 2006 & 0.0035 & 0.0062 & 0.0125 \\
\hline & & Mar-May, 2006 & 0.0034 & 0.0091 & 0.0117 \\
\hline & & Aug-Sep, 2006 & 0.0048 & 0.0090 & 0.0115 \\
\hline & & Sep-Oct, 2006 & 0.0058 & 0.0089 & 0.0115 \\
\hline \multirow{2}{*}{ Zhou et al. (2009) } & Changping, Beijing (town) & Summer 2005 & 0.0046 & 0.0063 & 0.0127 \\
\hline & Taicang, Jiangsu (suburban) & Summer 2005 & 0.0126 & 0.0077 & 0.0095 \\
\hline Verma et al. (2010) & Guangzhou, Guangdong (urban) & Jul 2006 & 0.0054 & 0.0089 & 0.0103 \\
\hline Li et al. (2007) & Xianghe, Hebei (rural) & Mar 2005 & 0.0101 & 0.0104 & 0.0129 \\
\hline \multicolumn{6}{|l|}{$\mathrm{OC} / \mathrm{BC}$} \\
\hline \multirow{2}{*}{ Yang et al. (2011) } & Miyun, Beijing (rural) & $2005-2008$ & 1.8 & 1.3 & 1.6 \\
\hline & THU, Beijing (urban) & 2005-2008 & 1.7 & 1.3 & 1.6 \\
\hline \multirow{5}{*}{ Gu et al. (2010) } & \multirow{5}{*}{ Tianjin (urban) } & Jan 2008 & $2.0^{4}$ & 1.8 & 2.0 \\
\hline & & Apr 2008 & $2.1^{4}$ & 1.5 & 1.5 \\
\hline & & Jul 2008 & $1.4^{4}$ & 1.2 & 1.7 \\
\hline & & Oct 2008 & $1.7^{4}$ & 1.5 & 1.5 \\
\hline & & Fall 2005 & 4.1 & 2.4 & 1.9 \\
\hline \multirow{3}{*}{ Han et al. (2008) } & \multirow{3}{*}{ Daihai, Inner Mongol (rural) } & Winter 2006 & 6.1 & 2.2 & 1.9 \\
\hline & & Summer 2006 & 2.5 & 2.3 & 1.8 \\
\hline & & Spring 2007 & 1.8 & 1.9 & 1.5 \\
\hline Andreae et al. (2008) & Guangzhou, Guangdong (urban) & Oct-Nov, 2004 & 1.4 & $1.5^{5}$ & $1.5^{5}$ \\
\hline
\end{tabular}

east China) during the same period and found a much higher $\mathrm{dBC} / \mathrm{dCO}$ in Taicang than Beijing. However, this big diversity is not well indicated by the bottom-up emission inventory, with just a slightly higher local $\mathrm{BC} / \mathrm{CO}$ emission ratio for Jiangsu province than Beijing. Although the large population of gasoline vehicles in Beijing and the diesel use by shipping in east China helped generate higher $\mathrm{BC} / \mathrm{CO}$ emission ratio for Jiangsu than Beijing, the more consumption of residential coals with elevated $\mathrm{BC} / \mathrm{CO}$ in Beijing than Jiangsu partly compensated the difference. Further studies are thus recommended on differentiated emission characteristics by region and sector.

The comparisons of OC/BC ratios are shown in Table 4 as well. The minimum $\mathrm{OC} / \mathrm{BC}$ slopes from observation, if available, are used in the comparisons to eliminate the effects of secondary organic aerosols as much as possible. The ratios from estimated emissions are generally close to observed slopes, enhancing confidence in the bottom-up emission inventory for primary carbonaceous aerosols. However, the estimated emissions fail to capture the very high $\mathrm{OC} / \mathrm{BC}$ ratios in rural Inner Mongolia in fall and winter (Han et al., 2008), suggesting that the current inventory might miss or underestimate emissions from some sources that generate large amounts of OC, such as biofuel use and biomass open burning. Besides short-term observations, relatively long-term observations (2005-2008) of BC and OC have also been conducted in both urban and rural Beijing (Yang et al., 2011). That the ratios from regional (north-central China) emissions are closer to the observed slopes than local (Beijing) emissions indicates that sources outside Beijing contribute substantially to carbonaceous aerosol levels. Although BC emissions in Beijing are estimated to have declined by $22 \%$ from 2005 to 2008, BC concentrations in urban Beijing did not decline much, and observed BC levels in rural Beijing in fact increased by $21 \%$ (Yang et al., 2011), resulting mainly from increased $\mathrm{BC}$ emissions in nearby provinces.

\subsection{Comparisons with satellite observation}

$\mathrm{SO}_{2}$ and $\mathrm{NO}_{2}$ retrievals from satellite observations are used for comparisons to the primary emissions estimated in this work. Data for $\mathrm{SO}_{2}$ VCDs of are from the Scanning 


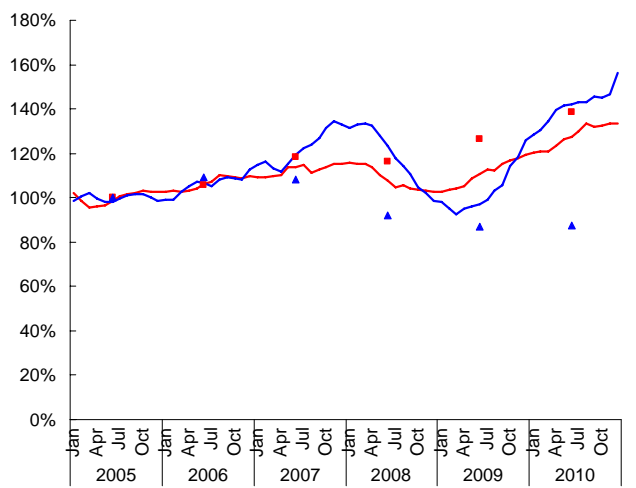

(a) NC

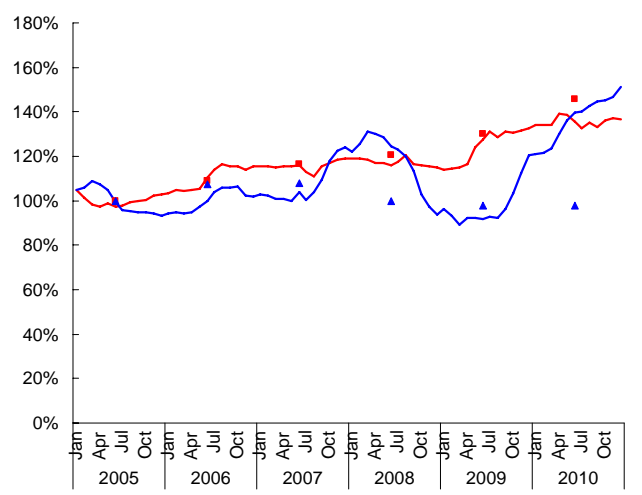

(b) $\mathrm{NE}$

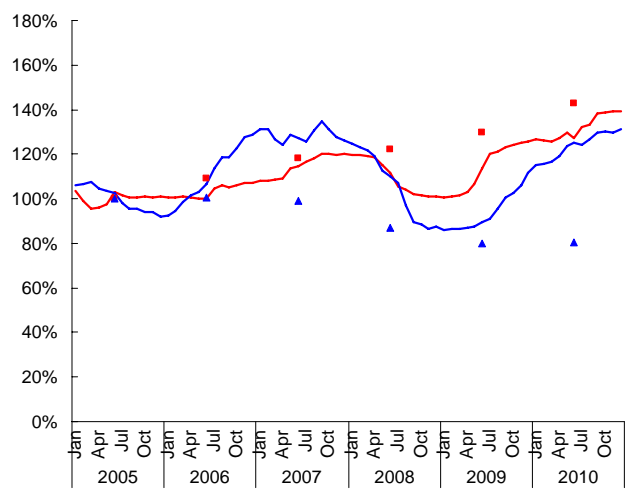

(c) $\mathrm{E}$

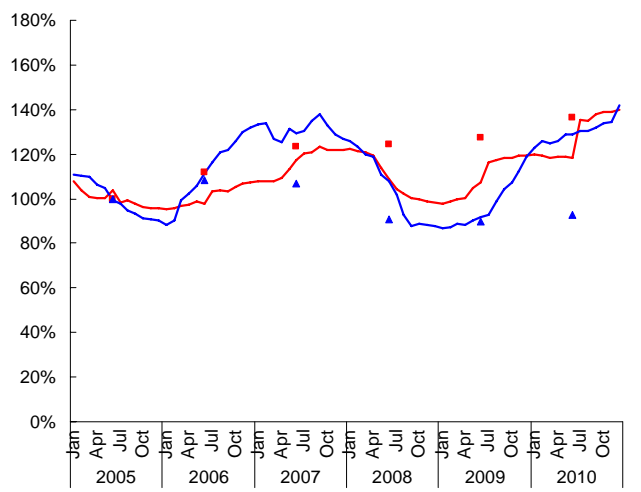

(d) SC

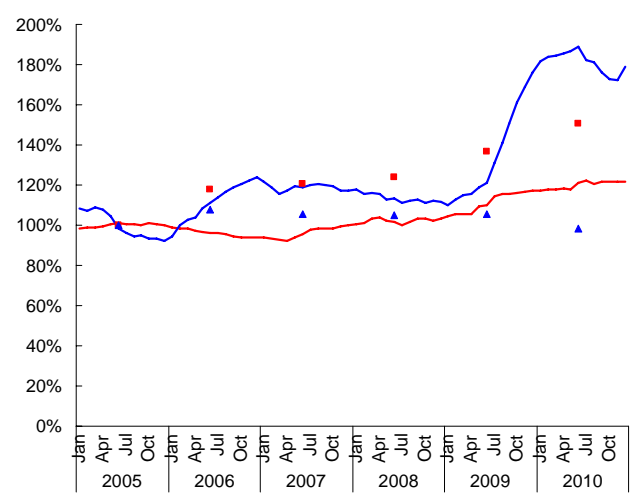

(e) SW

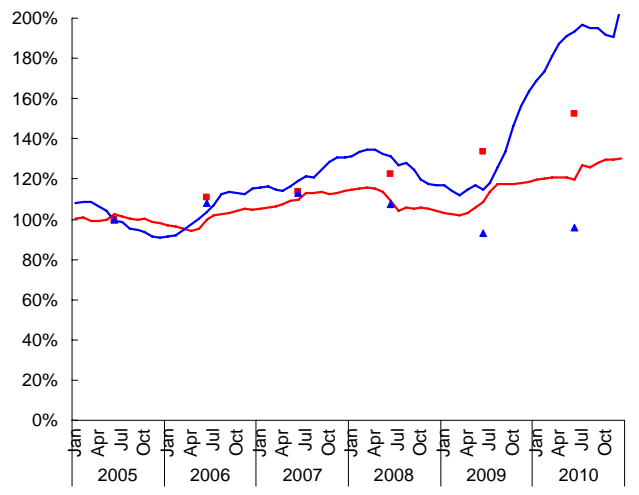

(f) $\mathrm{NW}$

- Estimated annual NOx emissions Estimated annual SO2 emissions

Fig. 5. The comparisons of inter-annual trends between satellite observation and bottom-up emissions from 2005 to 2010 . All the data are normalized to 2005 levels.

Imaging Absorption Spectrometer for Atmospheric CHartographY (SCIAMACHY), and the monthly level-3 product with spatial resolution of $0.25^{\circ} \times 0.25^{\circ}$ from Support to Aviation Control Service (SACS) is used (data source: http://sacs.aeronomie.be/archive/month/index_VCD_ month.php). To approximate the effects of anthropogenic activities, it is assumed that the $\mathrm{SO}_{2}$ is in the lowest $2 \mathrm{~km}$ above the surface, i.e., that $\mathrm{SO}_{2}$ is found only in the plan- etary boundary layer. The VCDs of tropospheric $\mathrm{NO}_{2}$ are from the Ozone Monitoring Instrument (OMI), retrieved by the Royal Netherlands Meteorological Institute (Boersma et al., 2007; 2011), and the monthly data with spatial resolution of $0.125^{\circ} \times 0.125^{\circ}$ are used (data source: http://www.temis.nl/ airpollution/no2col/no2regioomimonth_v2.php). The annual means of $\mathrm{SO}_{2}$ and $\mathrm{NO}_{2} \mathrm{VCDs}$ over mainland China for 


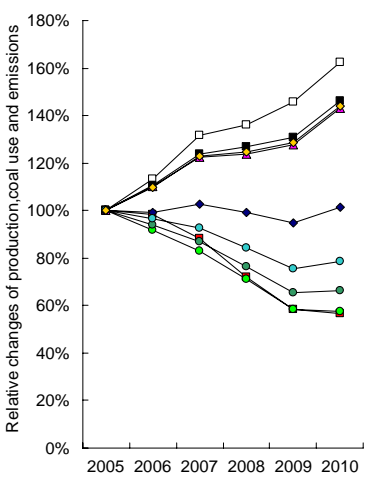

(a) Coal-fired power plants

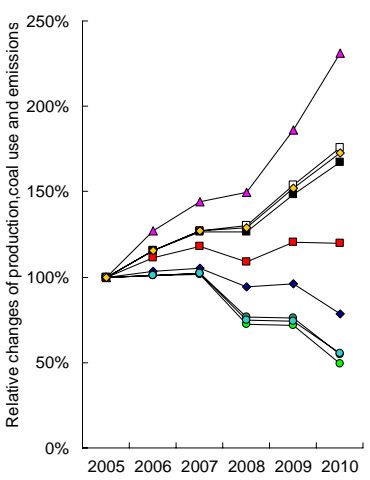

(b) Cement production

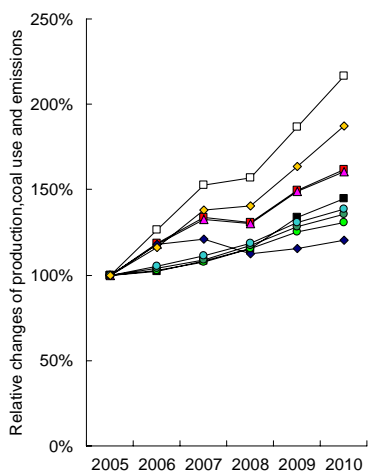

(c) Iron \& steel production

$\rightarrow \square-$ Electricity/cement/steel production $\rightarrow-$ Coal consumption

$\rightarrow$ SO2 $\triangle$ NOx $\rightarrow$-TSP $\rightarrow$ PM10 $\rightarrow$ - PM2.5 $\rightarrow \mathrm{CO} \leadsto-\mathrm{CO} 2$

Fig. 6. Relative changes of production, coal consumption and emissions for coal-fired power plants (a), cement plants (b) and iron and steel plants (c) from 2005 to 2010 . Note the scales are different for the three panels.

2005-2010 are calculated based on the monthly data and are shown in Figs. S3 and S4 in the Supplement.

Figure 5 illustrates the trends of monthly VCDs of tropospheric $\mathrm{SO}_{2}$ and $\mathrm{NO}_{2}$ from satellite observations and of annual emissions of $\mathrm{SO}_{2}$ and $\mathrm{NO}_{\mathrm{x}}$, from 2005 to 2010 by region. To eliminate seasonal variations, the satellite observations are presented as 12-month moving averages, calculated as the means of the data for the previous and subsequent six months. All values are normalized to 2005 levels, to reflect relative changes during the study period. Generally, the growth of tropospheric $\mathrm{NO}_{2}$ is consistent with the trends of bottom-up annual emissions, confirming increasing $\mathrm{NO}_{\mathrm{x}}$ pollution in mainland China. Specifically, the emissions and observations match well for developed regions including north-central, east, and south-central China. In the west of the country, however, bigger discrepancy is found between the growth trends of emissions and VCDs (Fig. 5e-f). This is partly because the random retrieval errors of satellite observation can be significant over western regions with relatively clean environment and low $\mathrm{NO}_{2}$ values. Emissions from natural sources (such as soil and lighting), which had not grown as much as anthropogenic emissions, could contribute more to the VCDs than they do in the developed eastern regions (Lin et al., 2010b). Moreover, the estimated emissions fail to fully capture the drop of $\mathrm{NO}_{2}$ during late 2008-early 2009, attributed to limits on economic activities and energy consumption to improve air quality for the Beijing Olympics (Wang et al., 2010b) and/or economic downturn in the country (Lin et al., 2011). This discrepancy reveals the limits of emission inventories at annual temporal resolution to reflect responses to short-term variations of economic activity and control policies at local or regional scales.

The comparisons for $\mathrm{SO}_{2}$ are perplexing. As shown in Fig. 5, the $\mathrm{SO}_{2}$ VCDs are observed to increase first with a subsequent abatement during 2005-2009, consistent with the trends of estimated emissions. The trends are confirmed as well by Fig. S4a-e in the Supplement, showing that the areas with relatively high $\mathrm{SO}_{2} \mathrm{VCDs}$ in mainland China expanded from 2005 to 2007 but then shrank in the following two years. Nevertheless, the observed $\mathrm{SO}_{2}$ rebounded again from late 2009 or early 2010 for all regions, while little increase in bottom-up emissions is estimated. The disagreement can come from either or both the uncertainties of emission estimation and satellite observations. On one hand, as analyzed in Sect. 4.3, the unclear operation levels of FGD systems in China's power plants contribute significantly to the uncertainty of national $\mathrm{SO}_{2}$ emissions, particularly for the most recent years with greater penetration of FGD in power sector. On the other hand, the exaggerated growth of $\mathrm{SO}_{2}$ columns particularly for 2010 (Fig. S4f) could also be from the highly uncertain satellite data retrieval due to variations of atmospheric conditions including the varied aerosol absorption and conversion efficiency of $\mathrm{SO}_{2}$ to sulfate, as suggested by Lu et al. (2011). The discrepancy between emissions and observation has been realized by SACS and reduced uncertainty of data retrieval is expected through reprocessing of $\mathrm{SO}_{2}$ VCDs from SCIAMACHY (personal communication with SACS).

\section{Discussion}

\subsection{The effects of policy on emission abatement}

During 2005-2010, substantial efforts were undertaken in China to achieve national targets in both energy conservation and emission reduction, particularly in sectors of power generation, cement production, and iron and steel production. Figure 6 illustrates the inter-annual trends of production, coal consumption, and emissions for the three sectors from 2005 to 2010 .

For the power sector, as shown in Fig. 6a, the electricity generated from coal-fired plants increased $62 \%$ during 
2005-2010, while coal consumption by the power sector increased $46 \%$, reflecting the progress of energy conservation in the sector. This is mainly due to the replacement of small and old power units with more energy-efficient large units (e.g., super-critical and ultra super-critical units), reducing the coal consumption per unit electricity generation by $10 \%$, from 370 to 335 grams of coal equivalent per unit kilowatthour $\left(\mathrm{gce} \mathrm{kWh}^{-1}\right.$ ) (updated from previous work by Zhao et al., 2008). The higher penetration of large units raised as well the application of advanced emission control technologies for PM (e.g., ESP and FF) and $\mathrm{SO}_{2}$ (e.g., wet-FGD systems), resulting in strong emission abatement of the two pollutants, by $46 \%$ and $42 \%$ respectively from 2005 to 2010 . The annual emissions of $\mathrm{NO}_{\mathrm{x}}$ and $\mathrm{CO}_{2}$, however, had similar growth trends as that of coal consumption, indicating that current control of these two species depends significantly on growth of energy consumption. Although the penetration of SCR technology reached $10 \%$ in the power sector in 2010, the actual effects on $\mathrm{NO}_{\mathrm{x}}$ control cannot yet be verified (Zhao et al., 2010), in the same manner that FGD has not taken full control effect on $\mathrm{SO}_{2}$ in recent years. Since coal will continue to dominate the energy structure of China's electricity generation in the near future, the improvement of SCR use, in terms not only of penetration in the sector but also of operational performance and removal efficiency, is likely the most effective way to constrain growth of $\mathrm{NO}_{\mathrm{x}}$ emissions from coal-fired power plants.

As shown in Fig. 6b, cement production has increased by $76 \%$ from 2005 to 2010, and the actual production of 1.9 billion metric tons in 2010 already exceeded the prediction for 2020 of an analyses using a computable general equilibrium (CGE) economic model (Lei et al., 2011b). The dramatic growth of cement production, together with that of steel (described later), reflects the unexpectedly swift development of infrastructure facilities in the past few years in China. Meanwhile, the increased penetration of precalciner kilns has improved sector-wide combustion efficiency and expanded the use of emission control devices like FF, leading to considerable reduction of $\mathrm{CO}$ and $\mathrm{PM}$. However, $\mathrm{NO}_{\mathrm{x}}$ emissions increased by $130 \%$ during the study period, resulting both from the swift growth of cement production and the higher $\mathrm{NO}_{\mathrm{x}}$ emission levels produced by precalciner kilns compared to other kilns. This tension between improved technology and increased $\mathrm{NO}_{\mathrm{x}}$ emissions in the cement industry indicates that current policies are far from sufficient to reduce associated $\mathrm{NO}_{\mathrm{x}}$ emissions, and suggests that SCR/SNCR systems need to be promoted in the sector in the future.

During 2005-2010, iron and steel production increased by $116 \%$, while the coal consumption of smelting and pressing of ferrous metals increased by only $45 \%$ (Fig. 6c). This big achievement in energy saving resulted mainly from the retirement of small steel production plants and the increased use of recycled gas in coke ovens, blast furnaces, and basic oxygen furnaces (Zhao et al., 2012a). However, those improvements had very limited effects on the sintering process, leading to continued growth of $\mathrm{SO}_{2}$ and $\mathrm{NO}_{\mathrm{x}}$ emissions. Moreover, $\mathrm{PM}$ emissions from the iron and steel industry are estimated to have increased as well, resulting mainly from the fugitive emissions from coking, pig iron production, and casting processes. Among all the species, $\mathrm{CO}_{2}$ emissions are estimated to have increased fastest, by $87 \%$ from 2005 to 2010, although this growth rate is still lower than that of production. Generally, technology improvement in the sector have had some emission control effect but not to the extent of reversing growth of emissions of any species. A way to further abate emissions would be to increase the penetration of electric arc furnaces in steel making, which employs a short flow process (i.e., reuses waste steel in the material flow) and thus has much higher energy efficiency and lower emission factors than basic oxygen furnaces.

As a summary, although emission control was implemented in some key sectors, the emission trends of given species (e.g., $\mathrm{NO}_{\mathrm{x}}$ and $\mathrm{CO}_{2}$ ) are still largely driven by the underlying activity levels, i.e., energy consumption or industrial production. Because of the economic downturn from late 2008 to early 2009, there was a clear leveling off of energy and industrial production at that time, leading to slowed growth in $\mathrm{NO}_{\mathrm{x}}$ and $\mathrm{CO}_{2}$ emissions. However, starting in 2009 , emissions accelerated again corresponding to the policy to stimulate the economy including enormous investments in infrastructure construction. This strong dependence of emissions on the economy and energy implies that there are still major challenges in emission abatement in China as the economy continuously develops.

\subsection{Implications of emission trends of different aerosol species}

From 2005 to 2010, China's emissions of TSP, $\mathrm{PM}_{10}$ and $\mathrm{PM}_{2.5}$ are estimated to have decreased by $14 \%, 10 \%$ and $6 \%$, respectively. The lesser abatement of fine particles indicates more difficulty in emission control than the coarse fraction. In recent years, although penetration of dust collectors into industrial process sources has grown, many of them are cyclones or wet scrubbers, with much lower removal efficiencies for fine particles than TSP. FF systems, which are considerably more effective at $\mathrm{PM}_{2.5}$ control, are still applied at limited sources including power, cement, and iron \& steel plants. Similarly the emissions of BC and OC were less reduced than TSP, since the main sources of those species are residential small stoves burning solid fuels and open biomass burning, with very few technology improvements successfully deployed during recent years. Since fine particles and carbonaceous primary aerosols are much more closely associated with public health and radiative forcing than TSP, there is an urgent need for control measures targeting those aerosol species, particularly for industrial processes and residential fuel combustion.

Reduced emissions of PM and thereby alkaline base cations with acid-neutralizing effects may increase the 


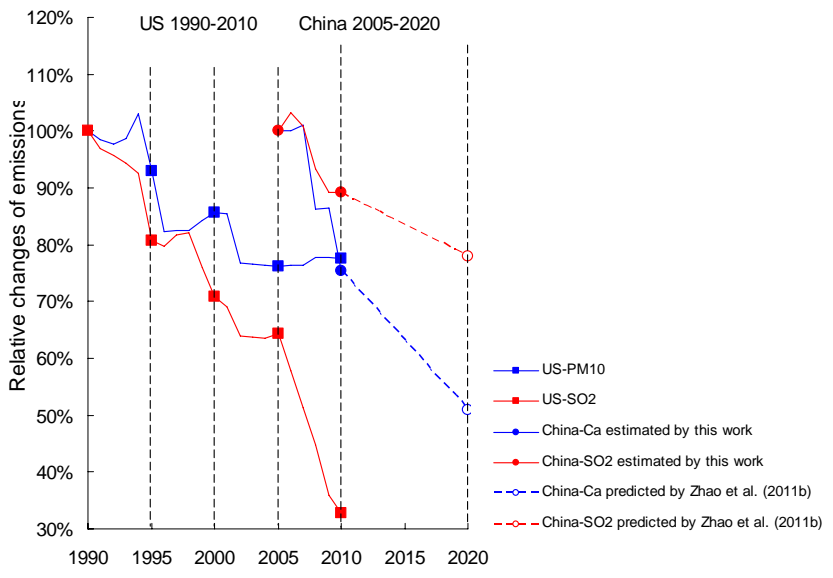

Fig. 7. Relative changes of $\mathrm{SO}_{2}$ and $\mathrm{PM}_{10} / \mathrm{Ca}$ emissions for USA 1990-2010 and China 2005-2020.

ecosystem acidification risks in China. From 2005 to 2010, $\mathrm{Ca}$ emissions are estimated to have declined by $25 \%$, while $\mathrm{SO}_{2}$ emissions by only $11 \%$, as shown in Fig. 7. The emission reduction rates of 2005-2010 are faster than those of a longer-term trend projected by the authors on the basis of current policy commitments, which suggest that China's base cation and $\mathrm{SO}_{2}$ emissions will decline $49 \%$ and $22 \%$ from 2005 to 2020, respectively (Zhao et al., 2011b). In contrast, the US national emissions of $\mathrm{SO}_{2}$ and $\mathrm{PM}_{10}$ (as a surrogate for base cations, since no emission of base cation was reported) are officially reported to have declined $36 \%$ and $24 \%$, respectively, from 1990 to 2005 , the 15 years following enactment of the 1990 amendments to the Clean Air Act (USEPA, 2012). Even with this aggressive level of $\mathrm{SO}_{2}$ abatement in the US, it was estimated that the amendments would not be adequate to protect surface waters and forest soils of the northeastern US against further anthropogenic acidification based on long-term observation of a forest catchment (Likens et al., 1996). From 2005 to 2010, another $50 \%$ of US $\mathrm{SO}_{2}$ emissions were reduced while $\mathrm{PM}_{10}$ emissions kept relatively stable (Fig. 7). Comparing the situations of the two countries, the much smaller percentage decline of $\mathrm{SO}_{2}$ and much larger decline of base cations in China indicate that recovery of acidification in the country may be more difficult under current control policies than the US experienced in 1990-2010. Recently, a long-term monitoring study found an association between increased acidity of precipitation and decreased PM concentrations at many sites across China, which cannot be explained by changes in natural sources (Tang et al., 2009). The observation confirmed increased acidification risks due to decreased anthropogenic base cations over the country. Since PM control efforts will doubtlessly continue in China to achieve important benefits of reduced aerosol pollution and avoided damages to public health, little other choice is available to alleviate acidification but to pursue even more stringent $\mathrm{SO}_{2}$ controls.

\subsection{The spread of air pollution challenges from urban centers to less developed areas}

While China's mega cities have been suffering from poor air quality for a long time (Parrish and Zhu, 2009), satellite observations suggest that even faster growth of air pollutants such as $\mathrm{NO}_{2}$ is now seen in less densely developed regions compared to mega cities (Zhang et al., 2012b). As shown in Fig. S3 in the Supplement, very limited increase in tropospheric $\mathrm{NO}_{2}$ VCDs was found in the developed Yangtze River Delta from 2005 to 2010; indeed there was even a small reduction in $\mathrm{NO}_{2} \mathrm{VCD}$ in the mega city of Shanghai. In contrast, much larger growth (exceeding $20 \%$ during 2005-2010) was found for the less developed areas adjacent to Shanghai and the Delta, such as north Jiangsu and Anhui provinces. Similarly, the $\mathrm{NO}_{2}$ increase during the five years in the mega city of Beijing (around $20 \%$ ) was much smaller than that in nearby provinces including Tianjin and Hebei (over $40 \%$ ) during 2005-2010. These trends indicate that China's air pollution challenges have been expanding from developed urban areas to nearby regions, explained partly by changes in anthropogenic activities and thereby emissions. In recent years, China's rapid urbanization of relatively small cities and development policies targeting interior regions have spread economic growth to less developed areas, resulting in increased industrial production and energy consumption. Meanwhile, tightened emission controls in the most highly developed, heavily polluted urban areas has lead to relocation of major emission sources from urban to rural regions. Based on county-level economic data provided by the China Data Center, University of Michigan (http://chinadataonline.org/), the fraction of national GDP generated by "secondary industry" (including mining, manufacturing, and construction) in China's urban areas is estimated to have declined from $54 \%$ to $48 \%$ during 2005 2010. The fraction of capacity of coal-fired power plants in urban areas decreased from $56 \%$ to $47 \%$, according to the updated unit-level database of power plants by Zhao et al. (2008). Moreover, the emissions of on-road transportation, which has contributed an increasing share of urban pollution, have been gradually controlled through the implementation of staged emission standards, while those of small industrial boilers and residential stoves, which dominate rural emissions, have not. At the provincial level, Table 5 provides the fractions of the sum of China's most developed provinces to the national total in typical activity levels and emissions of different species for 2005 and 2010. The provinces include Beijing and Tianjin in the North China Plain; Shanghai, Jiangsu, and Zhejiang, encompassing the Yangtze River Delta; and Guangdong, which includes the Pearl River Delta. The lower values for 2010 than 2005 in all the entries in Table 5 confirm that China's economic activities, energy consumption, and emissions have been shifting proportionately to poorer areas. Thus national air pollution control strategies 
Table 5. The fractions of the sum of developed provinces (including Beijing, Tianjin, Shanghai, Jiangsu, Zhejiang, and Guangdong) to total country in activity levels and emissions for 2005 and 2010.

\begin{tabular}{lcc}
\hline & $\begin{array}{c}\text { The fractions of } \\
\text { developed provinces } \\
\text { to total country }\end{array}$ \\
\cline { 2 - 3 } & 2005 & 2010 \\
\hline Activity levels & \\
\hline Capacity of coal-fired power plants & $28 \%$ & $24 \%$ \\
Cement production & $28 \%$ & $22 \%$ \\
Steel production & $30 \%$ & $28 \%$ \\
Coal consumption & $18 \%$ & $17 \%$ \\
On-road vehicle population & $36 \%$ & $34 \%$ \\
\hline Emissions & & \\
\hline $\mathrm{SO}_{2}$ & $22 \%$ & $17 \%$ \\
$\mathrm{NO}_{\mathrm{x}}$ & $28 \%$ & $24 \%$ \\
$\mathrm{CO}$ & $21 \%$ & $18 \%$ \\
$\mathrm{PM}_{\mathrm{CO}}$ & $19 \%$ & $16 \%$ \\
\hline
\end{tabular}

will increasingly need also to address conditions in those areas in the future.

\section{Conclusions}

Under pressures of enormous energy consumption and severe atmospheric pollution, China has been implementing a series of policies in energy conservation and emission reduction in recent years. These include the retirement of small and inefficient power and industrial plants, deployment and operation of FGD and SCR systems in the power sector, and implementation of staged emission control regulations for on-road vehicles. The measures have had varied impacts on the inter-annual trends of emissions of different atmospheric species. The emissions of $\mathrm{SO}_{2}$ and primary PM have been gradually reduced, although uncertainties around these emission estimates have increased from 2005 to 2010, mainly because of the weakly understood operational conditions of the swiftly increased FGD systems and the unclear penetration levels of dust collectors in key industrial sectors. Emissions of $\mathrm{NO}_{\mathrm{x}}$ and $\mathrm{CO}_{2}$ are estimated to have continued increasing, with average annual growth rates of $8.0 \%$ and $7.4 \%$ during 2005-2010, respectively, indicating the limited progress of current measures and ongoing major challenges in emission control of these two species. Although emission control policies greatly reduced TSP, fewer benefits were achieved for fine particles and carbonaceous aerosols, which contribute more to human health damages and climate forcing. Moreover, the estimated swift decline of alkaline base cations in primary $\mathrm{PM}$ compared to $\mathrm{SO}_{2}$ suggests rising acidification risks to ecosystems, as also indicated by long-term obser- vations at multiple sites across the country. There is thus a great future need for a comprehensive, multi-pollutant control strategy, consisting not of separately developed piecemeal policies targeting single atmospheric species but rather conceived to redress a complex of emissions and diverse environmental impacts.

In this work, emissions estimated bottom-up are compared with available observations from ground sites and satellites for different species, locations, and periods. While observations generally reflect inter-annual trends of emissions in most cases, clear discrepancies exist for given regions, seasons, or years. These discrepancies result from uncertainties both of observations and of bottom-up emissions. Data limits prevented full realization of regional and seasonal differentiations in activity levels, technology distributions, and emission factors for some sectors, particularly industrial processes and residential fuel combustion. Considering the rapidly changing complex of emission sources across China, further investigation of spatial and time distributions of contributing factors are needed to reduce uncertainties and to generate more accurate trends of emissions.

\section{Supplementary material related to this article is available online at: http://www.atmos-chem-phys.net/13/ 487/2013/acp-13-487-2013-supplement.pdf.}

Acknowledgements. This work was sponsored by the Natural Science Foundation of China (41205110), Natural Science Foundation of Jiangsu (BK2012310), US National Science Foundation (Grant ATM-1019134), and Ministry of Science and Technology of China (2011BAK21B00). We would like to thank TEMIS for free use of their monitoring data, and Hugues Brenot from SACS for the help on interpretation of satellite observation results. Thanks should also go to Jintai Lin from Peking University, Yu Lei from Chinese Academy for Environmental Planning, and two anonymous reviewers for their very valuable comments to improve this work.

Edited by: M. Kopacz

\section{References}

Andreae, M. O., Schmid, O., Yang, H., Chand, D., Yu, J. Z., Zeng, L. M., and Zhang, Y. H.: Optical properties and chemical composition of the atmospheric aerosol in urban Guangzhou, China, Atmos. Environ., 42, 6335-6350, 2008.

Akimoto, H., Ohara, T., Kurokawa, J, and Horii, N.: Verification of energy consumption in China during 1996-2003, Atmos. Environ., 40, 7664-7667, 2006.

Boersma, K. F., Eskes, H. J., Dirksen, R. J., van der A, R. J., Veefkind, J. P., Stammes, P., Huijnen, V., Kleipool, Q. L., Sneep, M., Claas, J., Leitão, J., Richter, A., Zhou, Y., and Brunner, D.: An improved tropospheric $\mathrm{NO}_{2}$ column retrieval algorithm for the Ozone Monitoring Instrument, Atmos. Meas. Tech., 4, 19051928, doi:10.5194/amt-4-1905-2011, 2011. 
Boersma, K. F., Eskes, H. J., Veefkind, J. P., Brinksma, E. J., van der A, R. J., Sneep, M., van den Oord, G. H. J., Levelt, P. F., Stammes, P., Gleason, J. F., and Bucsela, E. J.: Near-real time retrieval of tropospheric $\mathrm{NO}_{2}$ from OMI, Atmos. Chem. Phys., 7, 2103-2118, doi:10.5194/acp-7-2103-2007, 2007.

Chen, W. M., Wang, J. X., and Shuai, S. J.: The effects of fuel properties on diesel engine emissions (in Chinese), Automot. Eng., 30, 657-663, 2008.

China Iron and Steel Association (CISA): China Steel Yearbook 2005-2010, the Editorial Board of China Steel Yearbook, Beijing, 2011.

Cofala, J., Amann, M., Klimont, Z., Kupiainen, K., and HoglundIsaksson, L.: Scenarios of global anthropogenic emissions of air pollutants and methane until 2030, Atmos. Environ., 41, 84868499, 2007.

Gu, J. X., Bai, Z. P., Liu, A. X., Wu, L. P., Xie, Y. Y., Li, W. F., Dong, H. Y., and Zhang, X.: Characterization of Atmospheric Organic Carbon and Element Carbon of $\mathrm{PM}_{2.5}$ and $\mathrm{PM}_{10}$ at Tianjin, China, Aerosol. Air. Qual. Res., 10, 167-176, 2010.

Guan, D. B., Liu, Z., Geng, Y., Lindner, S., and Hubacek, K.: The gigatonne gap in China's carbon dioxide inventories, Nature Clim. Change, 2, 672-675, 2012.

Guo, H., Zhang, Q. Y., Yao, S., and Wang, D. H.: On-road remote sensing measurements and fuel-based motor vehicle emission inventory in Hangzhou, China, Atmos. Environ., 41, 3095-3107, 2007.

Han, S., Kondo, K., Oshima, N., Takegawa, N., Miyazaki, Y., Hu, M., Lin, P., Deng, Z., Zhao, Y., Sugimoto, N., and Wu, Y.: Temporal variations of elemental carbon in Beijing, J. Geophys. Res., 114, D23202, doi:10.1029/2009JD012027, 2009.

Han, Y. M., Han, Z. W., Cao, J. J., Chow, J. C., Watson, J. G., An, Z. S., Liu, S. X., and Zhang, R. J.: Distribution and origin of carbonaceous aerosol over a rural high-mountain lake area, Northern China and its transport significance, Atmos. Environ., 42, 2405-2414, 2008.

He, K. B., Yao, Z. L., and Zhang, Y. Z.: Characteristics of vehicle emissions in China based on portable emission measurement system, 19th Annual International Emission Inventory Conference "Emissions Inventories - Informing Emerging Issues", San Antonio, Texas, 27-30 September 2010. Available at: http: //www.epa.gov/ttnchie1/conference/ei19/session6/he.pdf

He, K. B., Huo, H., Zhang, Q., He, D. Q., An, F., Wang, M., and Walsh, M. P.: Oil consumption and $\mathrm{CO}_{2}$ emissions in China's road transport: current status, future trends, and policy implications, Energ. Policy, 33, 1499-1507, 2005.

Huo, H., He, K. B., Wang, M., and Yao, Z. L.: Vehicle technologies, fuel-economy policies, and fuel-consumption rates of Chinese vehicles, Energ. Policy, 43, 30-36, 2012a.

Huo, H., Zhang, Q., He, K. B., Yao, Z. L., and Wang, M.: Vehicleuse intensity in China: Current status and future trend, Energ. Policy, 43, 6-16, 2012b.

Huo, H., Yao, Z. L., He, K. B., and Yu, X.: Fuel consumption rates of passenger cars in China: Labels versus real-world, Energ. Policy, 39, 7130-7135, 2011.

Klimont, Z., Cofala, J., Xing, J., Wei, W., Zhang, C. Y., Wang, S. X., Jiang, K. J., Bhandari, P., Mathur, R., Purohit, P., Rafaj, P., Chambers, A., and Amann, M: Projections of $\mathrm{SO}_{2}, \mathrm{NO}_{\mathrm{x}}$, and carbonaceous aerosols emissions in Asia, Tellus Ser.B., 61B, 602-617, 2009.
Klimont, Z., Cofala, J., Bertok, I., Amann, M., Heyes, C., and Gyarfas, F.: Modeling Particulate Emissions in Europe: A framework to estimate reduction potential and control costs, Interim report, IR-02-076, International Institute for Applied Systems Analysis, Laxenburg, Austria, 2002.

Kondo, Y., Oshima, N., Kajino, M., Mikami, R., Moteki, N., Takegawa, N., Verma, R. L., Kajii, Y., Kato, S., and Takami, A.: Emissions of black carbon in East Asia estimated from observation at a remote site in the East China Sea, J. Geophys. Res., 116, D16201, doi:10.1029/2011JD015637, 2011.

Larssen, T., Lydersen, E., Tang, D. G., He, Y., Gao, J. X., Liu, H. Y., Duan, L., Seip, H. M., Vogt, R. D., Mulder, J., Shao, M., Wang, Y. H., Shang, H., Zhang, X. S., Solberg, S., Aas, W., Okland, T., Eilertsen, O., Angell, V., Liu, Q. R., Zhao, D. W., Xiang, R. J., Xiao, J. S., and Luo, J. H.: Acid rain in China. Environ. Sci. Technol., 40, 418-425, 2006.

Lei, Y., Zhang, Q., He, K. B., and Streets, D. G.: Primary anthropogenic aerosol emission trends for China, 1990-2005, Atmos. Chem. Phys., 11, 931-954, doi:10.5194/acp-11-931-2011, 2011a.

Lei, Y., Zhang, Q., Nielsen, C. P., and He, K. B.: An inventory of primary air pollutants and $\mathrm{CO}_{2}$ emissions from cement industry in China, 1990-2020, Atmos. Environ., 45, 147-154, $2011 \mathrm{~b}$.

Li, C., Zhang, Q., Krotkov, N. A., Streets, D. G., He, K. B., Tsay, S. C., and Gleason, J. F.: Recent large reduction in sulfur dioxide emissions from Chinese power plants observed by the Ozone Monitoring Instrument, Geophys. Res. Lett., 37, L08807, doi:10.1029/2010GL042594, 2010.

Li, C., Marufu, L. T., Dickerson, R. R., Li, Z. Q., Wen, T. X., Wang Y. S., Wang, P. C., Chen. H. B., and Stehr, J. W.: In situ measurements of trace gases and aerosol optical properties at a rural site in northern China during East Asian Study of Tropospheric Aerosols: An International Regional Experiment 2005, J. Geophys. Res., 112, D22S04, doi:10.1029/2006JD007592, 2007.

Likens, G. E., Driscoll, C. T., and Buso, D. C.: Long-term effects of acid rain: Response and recovery of a forest ecosystem, Science, 272, 244-246, 1996.

Lin, J. T. and McElroy, M. B.: Detection from space of a reduction in anthropogenic emissions of nitrogen oxides during the Chinese economic downturn, Atmos. Chem. Phys., 11, 8171-8188, doi:10.5194/acp-11-8171-2011, 2011.

Lin, J. T., Nielsen, C. P., Zhao, Y., Lei, Y., Liu, Y., and McElroy, M. B.: Recent changes in particulate air pollution over China observed from space and the ground: effectiveness of emission control, Environ. Sci. Technol., 44, 7771-7776, 2010a.

Lin, J. T., McElroy, M. B., and Boersma, K. F.: Constraint of anthropogenic NOx emissions in China from different sectors: a new methodology using multiple satellite retrievals, Atmos. Chem. Phys., 10, 63-78, doi:10.5194/acp-10-63-2010, $2010 \mathrm{~b}$.

Lu, Z., Zhang, Q., and Streets, D. G.: Sulfur dioxide and primary carbonaceous aerosol emissions in China and India, 1996-2010, Atmos. Chem. Phys., 11, 9839-9864, doi:10.5194/acp-11-98392011, 2011.

Lu, Z., Streets, D. G., Zhang, Q., Wang, S., Carmichael, G. R., Cheng, Y. F., Wei, C., Chin, M., Diehl, T., and Tan, Q.: Sulfur dioxide emissions in China and sulfur trends in East Asia since 2000, Atmos. Chem. Phys., 10, 6311-6331, doi:10.5194/acp-106311-2010, 22010. 
Ministry of Industry and Information Technology (MIIT): The direction of technology improvement and investment for automobile industry, available at: http://www.miit.gov.cn/n11293472/ n11293832/n12843956/n13227851.files/n13226869.xls (last access: 15 Januar 2013), 2010.

National Bureau of Statistics (NBS): China Statistical Yearbook 2005-2010, China Statistics Press, Beijing, China, 2011a.

National Bureau of Statistics (NBS): China Industry Economy Statistical Yearbook 2005-2010, China Statistics Press, Beijing, China, 2011b.

National Bureau of Statistics (NBS): China Statistical Yearbook 2005-2010, China Statistics Press, Beijing, 2011c.

Ohara, T., Akimoto, H., Kurokawa, K., Horii, N., Yamaji, K., Yan, X., and Hayasaka, T.: An Asian emission inventory of anthropogenic emission sources for the period 1980-2020, Atmos. Chem. Phys., 7, 4419-4444, doi:10.5194/acp-7-4419-2007, 2007.

Oliver, H. H.: In-use vehicle emissions in China-Tianjin Study, Discussion paper 2008-08, Harvard Kennedy School, available at: http://belfercenter.ksg.harvard.edu/files/2008_Oliver_In-use_ Vehicle_Emissions_Tianjin.pdf (last access: 15 Januar 2013), 2008.

Parrish, D. D. and Zhu, T.: Clean air for megacities, Science, 326, 674-675, 2009.

Richter, A., Burrows, J. P., Nuss, H., Granier, C., and Niemeier, U.: Increase in tropospheric nitrogen dioxide over China observed from space, Nature, 437, 129-132, 2005.

Shen, G. F., Wei, S. Y., Wei, W., Zhang, Y. Y., Wang, B., Wang, R., Li, W., Shen, H. Z., Huang, Y., Yang, Y. F., , Wang, X. L., Wang, $\mathrm{X}$. J., and Tao, S.: Emission factors, size distributions and emission inventories of carbonaceous particulate matter from residential wood combustion in rural China, Environ. Sci. Technol., 46, 4207-4214, 2012.

Shen, G. F., Yang, Y. F., Wang, W., Tao, S., Zhu, C., Min, Y. J., Xue, M., Ding, J .N., Wang, B., Wang R., Shen, H. Z., Li, W., Wang, X. L., and Russell, A. G.: Emission factors of particulate matter and elemental carbon for crop residues and coals burned in typical household stoves in China, Environ. Sci. Technol., 44, 7157-7162, 2010.

Streets, D. G., Zhang, Q., Wang, L. T., He, K. B., Hao, J. M., Wu, Y., Tang, Y. H., and Carmichael, G. R.: Revisiting China's CO emissions after the Transport and Chemical Evolution over the $\mathrm{Pa}$ cific (TRACE-P) mission: Synthesis of inventories, atmospheric modeling, and observations, J. Geophys. Res., 111, D14306, doi:10.1029/2006JD007118, 2006.

Tang, J., Xu, X. B., Ba, J., and Wang, S. F.: Trends of the precipitation acidity over China during 1992-2006, Chinese. Sci. Bull., 55, 1800-1807, 2010.

US Environmental Protection Agency (USEPA): Emission inventory information, available at http://www.epa.gov/ttn/chief/ trends/index.html (last access: 15 Januar 2013), 2012.

van Donkelaar, A., Martin, R. V., Brauer, M., Kahn, R., Levy, R., Verduzco, C., and Villeneuve, P. J.: Global estimates of ambient fine particulate matter concentrations from satellite-based aerosol optical depth: development and application, Environ. Health. Persp., 118, 847-855, 2010.

Verma, R. L., Sahu, L. K., Kondo, Y., Takegawa, N., Han, S., Jung, J. S., Kim, Y. J., Fan, S., Sugimoto, N., Shammaa, M. H., Zhang. Y. H., and Zhao, Y.: Temporal variations of black carbon in
Guangzhou, China, in summer 2006, Atmos. Chem. Phys., 10, 6471-6485, doi:10.5194/acp-10-6471-2010, 2010.

Wang, S. W., Zhang, Q., Streets, D. G., He, K. B., Martin, R. V., Lamsal, L. N., Chen, D., Lei. Y., and Lu, Z.: Growth in NOx emissions from power plants in China: bottom-up estimates and satellite observations, Atmos. Chem. Phys., 12, 4429-4447, 2012 , http://www.atmos-chem-phys.net/12/4429/2012/.

Wang, Y. X., Wang, X., Kondo, Y., Kajino, M., Munger, J. W., and Hao, J. M.: Black carbon and its correlation with trace gases at a rural site in Beijing: Top-down constraints from ambient measurements on bottom-up emissions, J. Geophys. Res., 116 D24304, doi:10.1029/2011JD016575, 2011.

Wang, Y. X., Munger, J. W., Xu, S., McElroy, M. B., Hao, J. M., Nielsen, C. P., and Ma, H.: $\mathrm{CO}_{2}$ and its correlation with $\mathrm{CO}$ at rural site near Beijing: implications for combustion efficiency in China, Atmos. Chem. Phys., 10, 8881-8897, doi:10.5194/acp10-8881-2010, 2010a.

Wang, S. X., Zhao, M., Xing, J., Wu, Y., Zhou, Y., Lei, Y., He, K. B. $\mathrm{Fu}, \mathrm{L}$. X., and Hao, J. M.: Quantifying the air pollutants emission reduction during the 2008 Olympic Games in Beijing, Environ. Sci. Technol., 44, 2490-2496, 2010b.

Wu, Y., Zhang, S. J., Li, M. L., Ge, Y. S., Wu, J. W., Zhou, Y., Xu, Y. Y., Hu, J. N., Liu, H., Fu, L. X., He, K. B., and Hao, J. M.: The challenge to $\mathrm{NO}_{\mathrm{x}}$ emission control for heavy-duty diesel vehicles in China, Atmos. Chem. Phys., 12, 9365-9379, doi:10.5194/acp12-9365-2012, 2012.

$\mathrm{Xu}, \mathrm{M}$. and Wang, Y. J.: The potential and countermove of energysaving and cutting pollution about brick and tile industry in China(in Chinese), Brick \& Tile World, 7, 6-11, 2007.

$\mathrm{Xu}, \mathrm{Y}$.: Improvements in the operation of $\mathrm{SO}_{2}$ scrubbers in China's coal power plants, Environ. Sci. Technol., 45, 380-385, 2011.

Xu, Y., Williams, R. H., and Socolow, R. H.: China's rapid deployment of $\mathrm{SO}_{2}$ scrubbers, Energy. Environ. Sci., 2, 459-465, 2009.

Yang, F., Huang, L., Duan, F., Zhang, W., He, K., Ma, Y., Brook, J. R., Tan, J., Zhao, Q., and Cheng, Y.: Carbonaceous species in PM2.5 at a pair of rural/urban sites in Beijing, 2005-2008, Atmos. Chem. Phys., 11, 7893-7903, doi:10.5194/acp-11-78932011, 2011.

Yao, Z. L., Huo, H., Zhang, Q., Streets, D. G., and He, K. B.: Gaseous and particulate emissions from rural vehicles in China, Atmos. Environ., 45, 3055-3061, 2011.

Zhang, C. Y., Wang, S. X., Xing, J., Zhao, Y., and Hao, J. M.: Current status and future projections of $\mathrm{NO}_{\mathrm{X}}$ emissions from energy related industries in China (in Chinese), Acta Scientiae Circumstantiae, 28, 2470-2479, 2008.

Zhang, Q., He, K. B., and Huo, H.: Cleaning China's air, Nature, 484, 161-162, 2012a.

Zhang, Q., Geng, G. N., Wang, S. W., Richter, A., and He, K. B.: Satellite remote sensing of changes in $\mathrm{NO}_{\mathrm{x}}$ emissions over China during 1996-2010, Chinese. Sci. Bull., 57, 2857-2864, 2012b.

Zhang, Q., Streets, D. G., Carmichael, G. R., He, K., Huo, H., Kannari, A., Klimont, Z., Park, I., Reddy, S., Fu, J. S., Chen, D., Duan, L., Lei, Y., Wang, L., and Yao, Z.: Asian emissions in 2006 for the NASA INTEX-B mission, Atmos. Chem. Phys., 9, 51315153, doi:10.5194/acp-9-5131-2009, 2009.

Zhang, Q., Streets, D. G., He, K., Wang, Y., Richter, A., Burrows, J. P., Uno, I., Jang, C. J., Chen, D., Yao, Z., and Lei, Y.: $\mathrm{NO}_{\mathrm{x}}$ emission trends for China, 1995-2004: The view from the 
ground and the view from space, J. Geo. Res., 112, D22306, doi:10.1029/2007jd008684, 2007.

Zhao, Y., Nielsen, C. P., McElroy, M. B., Zhang, L., and Zhang, J.: CO emissions in China: uncertainties and implications of improved energy efficiency and emission control, Atmos. Environ., 49, 103-113, 2012a.

Zhao, Y., Nielsen, C. P., and McElroy, M. B.: China's $\mathrm{CO}_{2}$ emissions estimated from the bottom up: Recent trends, spatial distributions, and quantification of uncertainties, Atmos. Environ., 59, 214-223, 2012b.

Zhao, Y., Nielsen, C. P., Lei, Y., McElroy, M .B., and Hao, J. M.: Quantifying the uncertainties of a bottom-up emission inventory of anthropogenic atmospheric pollutants in China, Atmos. Chem. Phys., 11, 2295-2308, doi:10.5194/acp-11-2295-2011, 2011a.

Zhao, Y., Duan, L., Lei, Y., Xing, J., Nielsen, C. P., and Hao, J. M.: Will PM control undermine China's efforts to reduce soil acidification, Environ. Pollut., 159, 2726-2732, 2011 b.

Zhao, Y., Wang, S. X., Nielsen, C. P., Li, X. H., and Hao, J. M.: Establishment of a database of emission factors for atmospheric pollutants from Chinese coal-fired power plants, Atmos. Environ., 44, 1515-1523, 2010.
Zhao, Y., Duan, L., Xing, J., Larssen, T., Nielsen, C. P., and Hao, J. M.: Soil acidification in China: Is controlling $\mathrm{SO}_{2}$ emissions enough, Environ. Sci. Technol., 43, 8021-8026, 2009.

Zhao, Y., Wang, S. X., Duan, L., Lei, Y., Cao, P. F., and Hao, J. M.: Primary air pollutant emissions of coal-fired power plants in China: current status and future prediction, Atmos. Environ., 42, 8442-8452, 2008.

Zhou, X.: New ways of energy saving and emission control for brick and tile industry (in Chinese), Brick Tile World, 3, 15-19, 2009.

Zhou, X. H., Gao, J., Wang, T., Wu, W., and Wang, W. X.: Measurement of black carbon aerosols near two Chinese megacities and the implications for improving emission inventories, Atmos. Environ., 43, 3918-3924, 2009.

Zhu, X. Y., Duan, L., Tang, G. G., Hao, J. M., and Dong, G.: Estimation of atmospheric emissions of base cations in China (in Chinese), J. Tsinghua Univ. Sci. Technol., 44, 1176-1179, 2004.

Zielinska, B., Sagebiel, J., McDonald, J. D., Whitney, K., and Lawson, D. R.: Emission rates and comparative chemical composition from selected in-use diesel and gasoline-fueled vehicles, J. Air Waste Manage. Assoc., 54, 1138-1150, 2004. 